\title{
Quantitative proteomics and phosphoproteomics of urinary extracellular vesicles define diagnostic and prognostic biosignatures for Parkinson's Disease
}

Marco Hadisurya ${ }^{2}$, Li Li ${ }^{1}$, Kananart Kuwaranancharoen ${ }^{3}$, Xiaofeng Wu${ }^{4}$, Zheng-Chi Lee ${ }^{5}$, Roy N. Alcalay $^{6}$, Shalini Padmanabhan ${ }^{7}$, W. Andy Tao ${ }^{1,2,4,8,9^{*}}$, Anton Iliuk ${ }^{1,2^{*}}$

${ }^{1}$ Tymora Analytical Operations, West Lafayette, IN 47906

${ }^{2}$ Department of Biochemistry, Purdue University, West Lafayette, IN 47907

${ }^{3}$ School of Electrical and Computer Engineering, Purdue University, West Lafayette, IN 47907

${ }^{4}$ Department of Chemistry, Purdue University, West Lafayette, IN 47907

${ }^{5}$ West Lafayette Junior/Senior Highschool, West Lafayette, IN 47906

${ }^{6}$ Department of Neurology, Columbia University Irving Medical Center, New York, NY 10032

${ }^{7}$ The Michael J. Fox Foundation for Parkinson's Research, New York City, NY 10163

${ }^{8}$ Department of Medicinal Chemistry and Molecular Pharmacology, Purdue University, West Lafayette, IN 47907

${ }^{9}$ Purdue Center for Cancer Research, Purdue University, West Lafayette, IN 47907

*To whom correspondence should be addressed. Email: watao@purdue.edu; anton.iliuk@tymora-analytical.com 
medRxiv preprint doi: https://doi.org/10.1101/2022.01.18.22269096; this version posted January 24, 2022. The copyright holder for this preprint (which was not certified by peer review) is the author/funder, who has granted medRxiv a license to display the preprint in perpetuity.

All rights reserved. No reuse allowed without permission.

\section{Abstract}

Mutations in the leucine-rich repeat kinase 2 (LRRK2) gene have been recognized as genetic risk factors for both familial and sporadic forms of Parkinson's disease (PD). However, compared to cancer, overall lower genetic mutations contribute to the cause of PD, propelling the search for protein biomarkers for early detection of the disease. Utilizing 141 urine samples from four groups, healthy individuals (control), healthy individuals with G2019S mutation in the LRRK2 gene (non-manifesting carrier/NMC), PD individuals without G2019S mutation (idiopathic PD/iPD), and PD individuals with G2019S mutation (LRRK2 PD), we applied a proteomics strategy to determine potential diagnostic and prognostic biomarkers for PD from urinary extracellular vesicles (EVs). After efficient isolation of urinary EVs through chemical affinity followed by mass spectrometric analyses of EV peptides and enriched phosphopeptides, we identified and quantified 4,480 unique proteins and 2,682 unique phosphoproteins. We detected multiple proteins and phosphoproteins elevated in PD EVs that are known to be involved in important PD pathways such as neuronal cell death, neuroinflammation, autophagy, and formation of amyloid fibrils. We established two panels of proteins and phosphoproteins as novel candidates for disease and risk biomarkers, and substantiated using ROC, machine learning, and in-depth network analysis. Several disease biomarkers were further validated in patients with PD using parallel reaction monitoring (PRM) and immunoassay for targeted quantitation. These findings demonstrate a general strategy of utilizing biofluid EV proteome/phosphoproteome as an outstanding and non-invasive source for a wide range of disease exploration. 
medRxiv preprint doi: https://doi.org/10.1101/2022.01.18.22269096; this version posted January 24, 2022. The copyright holder for this preprint (which was not certified by peer review) is the author/funder, who has granted medRxiv a license to display the preprint in perpetuity.

All rights reserved. No reuse allowed without permission.

\section{Introduction}

It has been more than two centuries since Parkinson's disease (PD) was described by Dr. Parkinson in $1817^{1}$. PD is the second most common neurogenerative disorder after Alzheimer's disease $(A D)^{2}$. PD's most common pathological finding is a decreased pigmentation in the substantia nigra pars compacta (SNpc) caused by the death of dopaminergic neurons, leading to progressive deterioration of motor function ${ }^{3,4}$. In addition to motor symptoms, non-motor symptoms may include cognitive impairment, autonomic dysfunction, hyposmia, and sleep disturbances ${ }^{5}$. Currently, PD is incurable and progresses gradually with symptom deterioration into severe disabilities ${ }^{6}$. It has been estimated that PD affects 1 percent of the population over $60^{7}$. Overall, as many as 1 million Americans are living with PD, and approximately 60,000 Americans are diagnosed with PD each year ${ }^{8,9}$.

While the cause of PD is currently unknown, researchers speculate that environmental and genetic factors contribute to its development ${ }^{10}$. Large-scale genome-wide association studies (GWAS) have identified 41 independent risk variants for PD in various cohorts ${ }^{4,11}$. A subset of patients develops PD because of a major genetic risk. Specifically, mutations in the Leucine-rich repeat kinase 2 (LRRK2) gene are found in hereditary forms, emphasizing the shared molecular pathway driving both familial and non-familial PD to comprise the most common cause of the disease $^{12,13}$. Mutations in $L R R K 2$ have been recognized as genetic risk factors for sporadic ( 1\%) and familial forms of PD $(\sim 5 \%)^{13}$. LRRK2 encodes a large protein of 2,527 amino acids containing two functional enzymatic domains, the GTPase and the Ser/Thr kinase domains, and several protein-protein interaction domains such as the armadillo, ankyrin, leucine-rich repeat (LRR), and WD40 domains ${ }^{14,15}$. Out of many mutations in LRRK2, Gly2019 $\rightarrow$ Ser (G2019S) mutation in its kinase domain is by far the most common among caucasians ${ }^{16}$. Interestingly, some individuals with the G2019S mutation, known as the non-manifesting carrier (NMC) group, do not develop PD. Whether they will develop the disease at an older age remains unclear. 
medRxiv preprint doi: https://doi.org/10.1101/2022.01.18.22269096; this version posted January 24, 2022. The copyright holder for this preprint (which was not certified by peer review) is the author/funder, who has granted medRxiv a license to display the preprint in perpetuity.

All rights reserved. No reuse allowed without permission.

Recent findings regarding the Gly2019 $\rightarrow$ Ser (G2019S) mutation in the LRRK2 kinase domain have uncovered that the mutation drives changes in vesicular trafficking, autophagy, and lysosomal dysfunction signaling pathways ${ }^{16}$. The changes in these signaling pathways are attributed to the hyperactivation of the LRRK2 kinase activity assessed by phosphorylation of its substrates, the Rab proteins ${ }^{17}$. Rab proteins are the main regulators of important aspects of autophagy and lysosome activity, including membrane trafficking, vesicle formation, vesicle movement along actin and tubulin networks, and membrane docking and fusion. In short, from the evidence above, it is conceivable that the changes in signaling pathways caused by the Gly2019 $\rightarrow$ Ser (G2019S) mutation in the LRRK2 kinase domain may be reflected in extracellular vesicles (EVs). Therefore, EVs offer a promising source for protein biomarkers in PD.

EVs (primarily exosomes and microvesicles) are lipid bilayer-coated nanoparticles secreted by all cell types. The secretion of EVs was initially considered a means of eliminating proteins, lipids, and RNA from inside the cells ${ }^{18}$. With accumulating evidence, EVs have become recognized as a very important component in intercellular communication ${ }^{19}$. Recent studies have reported EVs as a rich resource of biomarkers for the non-invasive detection of neurodegenerative diseases from biofluids ${ }^{20}$. These EV-based disease markers can be identified well before the onset of symptoms or physiological detection of illness, making them promising candidates for early-stage PD diagnosis ${ }^{21,22}$. Moreover, since phosphorylation events directly reflect cellular physiological status during neurodegeneration, urinary EVs represent a highly promising source of phosphoproteins as non-invasive disease markers ${ }^{23,24}$. Previous studies from our group have identified numerous EV phosphoproteins in urine and plasma from breast cancer, chronic kidney disease, and kidney cancer patients ${ }^{25,26}$.

Here we present a strategy for the discovery and development of proteins and phosphoproteins from urinary EVs as diagnostic and prognostic biosignatures for Parkinson's disease. For the discovery experiment, we utilized 82 individual urine samples made available from Columbia University Irving Medical Center under a Michael J. Fox Foundation (MJFF)- 
medRxiv preprint doi: https://doi.org/10.1101/2022.01.18.22269096; this version posted January 24, 2022. The copyright holder for this preprint (which was not certified by peer review) is the author/funder, who has granted medRxiv a license to display the preprint in perpetuity.

All rights reserved. No reuse allowed without permission.

funded LRRK2 biomarker project ${ }^{27}$ and split them into 164 analyses (82 proteomics and 82 phosphoproteomics). We used our in-house developed unique EVtrap (E्xtracellular $\underline{\text { Vesicles total }}$ recovery and purification) approach to efficiently enrich EVs and coupled it with LC-MS-based detection and quantitation for accurate urinary EV proteome and phosphoproteome analysis. Our approach to date is the first such method to successfully demonstrate the feasibility of developing biofluid-derived EV phosphoproteins for disease profiling ${ }^{25,26}$. In total, we determined two panels of unique proteins and phosphoproteins as novel high-confidence candidates for disease and risk biomarkers. Disease biomarkers will help diagnose whether a patient currently has PD; on the other hand, risk biomarkers will predict the likelihood of developing PD in the future. Our largescale LC-MS analysis efforts combined with extensive bioinformatics analysis led to the discovery of unique biosignatures for potential Parkinson's disease diagnostics.

Furthermore, we also discovered important disease-relevant pathways that provided new information for PD intervention. These findings will enhance the discovery and development of novel EV protein-based biomarkers and help create an effective early-stage clinical diagnosis strategy for PD. An in-depth understanding of those biosignature pathways could also lead to the potential discovery of new drugs for optimal intervention strategies in PD progression.

\section{$\underline{\text { Results }}$}

Urine EV phosphoproteomics study design and sample quality control for PD biosignature development.

For decades, scientists have been focusing on PD genotype marker discovery. In the case of LRRK2 G2019S mutation diagnosis alone, people are often found to either have the mutation in their genome without even experiencing PD (non-manifesting carrier/NMC) or do not have the mutation in their genome although they are suffering from PD (idiopathic PD/iPD). Furthermore, whether people with diagnosed NMC will develop PD later in their lives remains unclear. Multiple recent studies have shown that analysis of proteins and phosphoproteins in many cases provides a better snapshot of cellular processes and disease progression than genomic or transcriptomic 
medRxiv preprint doi: https://doi.org/10.1101/2022.01.18.22269096; this version posted January 24, 2022. The copyright holder for this preprint (which was not certified by peer review) is the author/funder, who has granted medRxiv a license to display the preprint in perpetuity.

All rights reserved. No reuse allowed without permission.

investigations ${ }^{28-31}$. Proteome/phosphoproteome profiling efforts have already demonstrated significant advantages for disease diagnosis and prediction of treatment response ${ }^{32-35}$. This is particularly true for kinase-dependent conditions and kinase inhibitor drugs ${ }^{36-38}$. Using this study design, we have further confirmed what is already known in the PD research community - that genotype markers are unreliable. Therefore, there is a critical need to shift the focus to developing protein- and phosphoprotein-based biomarkers for PD detection instead. Since the LRRK2 G2019S mutation alters the phosphorylation activity and these changes are reflected in extracellular vesicles, this supports the rationale behind using EVs as promising biosignature sources for PD diagnosis and prognosis. Moreover, considering that many phosphorylation events directly reflect cellular physiological status, urinary EVs represent a highly promising source of proteins and phosphoproteins as non-invasive PD markers ${ }^{23,24}$. This is further reinforced by the recent studies showing Parkinson's disease relevance of LRRK2 phosphorylation in urinary $\mathrm{EVs}^{39-41}$ and LRRK2 G2019S mutation influence on neat urine proteome ${ }^{42}$.

Urine samples were collected at Columbia University Irving Medical Center (CUIMC) from four cohorts with or without PD, and with or without the common G2019S mutation in the LRRK2 gene $^{27}$. The samples were collected from March 2016 to April 2017 under a Michael J. Fox Foundation (MJFF)-funded LRRK2 biomarker project. The participants underwent clinical evaluation of their cognitive functions using the Montreal Cognitive Assessment (MoCA) and motor skills using the Unified Parkinson's Disease Rating Scale part III (UPDRS-III). This sample cohort has been uniquely curated for in-depth analysis and comparison of LRRK2 genotype and activity effects on PD as previously described ${ }^{27,43}$. These 141 samples were divided into three groups: the discovery experiment (82 samples) and two validation experiments (59 samples) (Figure 1). We were fully blinded to the identity of all samples until after the complete analysis. These four groups - control, NMC, iPD, and LRRK2 PD - were the major components of this biosignature study design. The demographic information for all samples is provided in Table 1. As shown, the four groups were balanced for all demographic variables. 


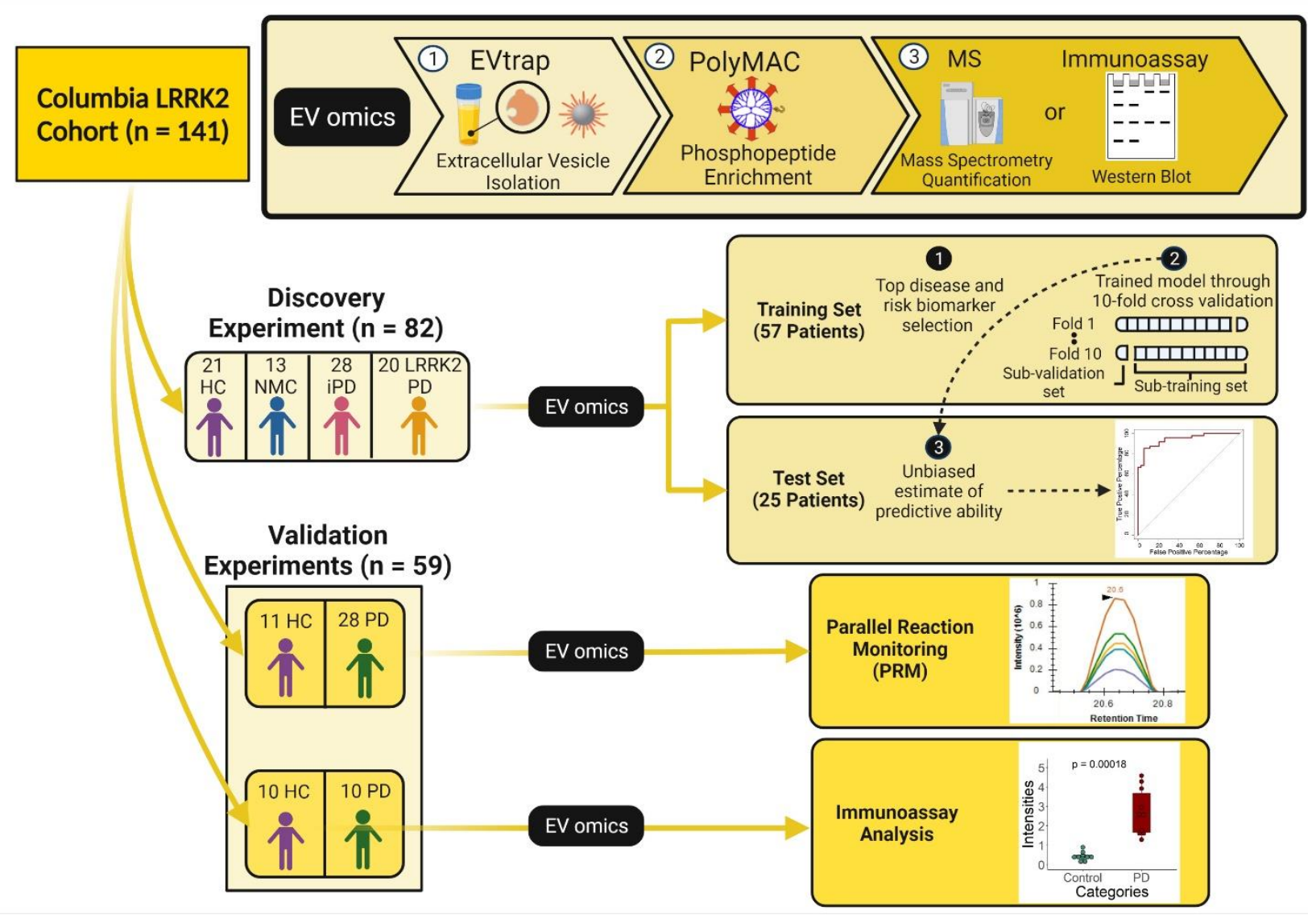

Figure 1. The development and validation of biomarker signatures for the diagnosis and prognosis of

Parkinson's Disease. A total of 141 urine samples were divided into two groups: the discovery and validation experiments. The urine samples were processed by using our in-house (1)EVtrap for EV isolation and (2PolyMAC (where applicable) for phosphopeptides enrichment. In the discovery experiment, the available 82 clinical urine samples were further randomly distributed into training and test sets for biomarker prediction. We proposed categorizing the potential biomarkers in 2 main categories: disease markers as the potential biomarkers for PD regardless of the LRRK2G2019S mutation and risk markers as the potential biomarkers for the risk of acquiring PD. Utilizing machine learning, we discovered the top disease and risk biomarkers. Furthermore, we also trained our model using the ten-fold crossvalidation and unbiasedly estimated the predictive ability on the test set. For biomarker validation, another 59 clinical urine samples were divided into two groups for parallel reaction monitoring (PRM) and immunoassay analysis. HC: healthy control, NMC: non-manifesting carrier, iPD: idiopathic Parkinson's Disease, LRRK2 PD: LRRK2 Parkinson's Disease, and PD: Parkinson's Disease. 
medRxiv preprint doi: https://doi.org/10.1101/2022.01.18.22269096; this version posted January 24, 2022. The copyright holder for this preprint (which was not certified by peer review) is the author/funder, who has granted medRxiv a license to display the preprint in perpetuity.

All rights reserved. No reuse allowed without permission.

\begin{tabular}{lccc|c|c}
\hline Demographics & Control & NMC & iPD & LRRK2PD & Overall \\
\hline $\begin{array}{l}\text { Age (range; years) } \\
\text { Gender }\end{array}$ & $69.4(59-85)$ & $58.5(37-83)$ & $66.1(45-82)$ & $69.7(56-90)$ & $66.6(37-90)$ \\
$\begin{array}{l}\text { (Female/Male) } \\
\begin{array}{l}\text { Disease Duration } \\
\text { (range; years) }\end{array}\end{array}$ & $10 / 11$ & $6 / 7$ & $3 / 4$ & $9 / 11$ & $37 / 45$ \\
MoCA & $\mathrm{n} / \mathrm{a}$ & $\mathrm{n} / \mathrm{a}$ & $0-18$ & $1-26$ & $0-26$ \\
UPDRS-III & $27.7(24-30)$ & $28.5(27-30)$ & $27.2(23-30)$ & $27.2(22-30)$ & $27.5(22-30)$ \\
\hline
\end{tabular}

Table 1. The summary of cohort demographics and clinical characteristics for all 82 patients whose samples were used in the discovery experiment. The range units for age and disease duration are in years. The groups include healthy individuals (control), healthy individuals with G2019S mutation in the LRRK2 gene (non-manifesting carrier/NMC), PD individuals without G2019S mutation (idiopathic PD/PD), and PD individuals with G2019S mutation (LRRK2 PD).

To evaluate the quality of samples and demonstrate the superior efficiency of isolating urinary EVs by EVtrap, we first selected a few representative samples and analyzed them using Tunable Resistive Pulse Sensing (TRPS), Western blotting with anti-CD9 and anti-LRRK2 antibodies, and LC-MS analyses. Nanoparticle size and distribution analysis with qNano (TRPS) of EVtrap- and ultracentrifugation (UC)-enriched urine EV samples both demonstrated a similar range of the isolated EVs, with the majority being in the $100-200 \mathrm{~nm}$ range (Supplementary Figs. 1a, b). Here, EVtrap showed a higher concentration of isolated EVs, as demonstrated in a previous publication ${ }^{44}$. Similarly, detection of CD9 and LRRK2 target proteins by Western blot from 5 randomly selected urine samples revealed a significant increase in signal levels for both proteins after EVtrap isolation compared to UC (Supplementary Fig. 1c). Finally, to show the reproducibility of our analytical procedure (from EVtrap enrichment to LC-MS analysis), we split a urine sample into six aliquots and processed them separately for LC-MS analysis.

Supplementary Fig. 2a demonstrates outstanding reproducibility of the procedure, with almost all of the proteins detected and quantified across all six samples falling under $10 \%$ coefficient of variation (CV) and the vast majority under $5 \% \mathrm{CV}$. 
medRxiv preprint doi: https://doi.org/10.1101/2022.01.18.22269096; this version posted January 24, 2022. The copyright holder for this preprint (which was not certified by peer review) is the author/funder, who has granted medRxiv a license to display the preprint in perpetuity.

All rights reserved. No reuse allowed without permission.

\section{Urinary EVs as prominent sources of PD biomarkers}

We processed 82 urine samples individually for the discovery experiment following the illustrated workflow in Supplementary Fig. $\mathbf{2 b}$ using approximately $10-15 \mathrm{~mL}$ of each urine after normalization by creatinine concentration. As the first step, we employed EVtrap to capture the complete EV profile from the urine samples using the synthesized magnetic beads described previously ${ }^{44}$. Following EV elution and drying, we lysed them with the optimized phase-transfer surfactant-based procedure to extract and denature proteins. After the reduction/alkylation step, the proteins were digested with sequential Lys-C and trypsin additions, and the resulting peptides were desalted. Here, a small portion of each sample ( 1\%) was used for direct proteomic analysis. We carried out phosphopeptide enrichment using our in-house developed dendrimer-based PolyMAC method on the remaining majority of each sample and analyzed by LC-MS. Indexed Retention Time Standard containing 11 artificial synthetic peptides was added to all proteomic and phosphoproteomic samples for improved peptide quantitation and reproducibility. The samples were analyzed by Thermo Fisher Q-Exactive HF-X MS coupled with the Ultimate 3000 UHPLC system.

Our urinary EV proteomic and phosphoproteomic analyses identified and quantitated 4,480 unique proteins from 46,240 peptide groups and 2,682 unique phosphoproteins from 10,620 phosphopeptide groups (see Fig. 2a for quantified features). We evaluated whether our identified EV proteins and phosphoproteins were a good source for PD assessment. We compared our data with the brain-specific RNA-seq data downloaded from the Human Protein Atlas website ${ }^{45}$. We used 2,587 proteins classified as brain-elevated from the Human Protein Atlas dataset to compare our EV protein and phosphoprotein data. We found that $8.9 \%$ of our EV proteins were denoted as brain-elevated (Supplementary Fig. 3). While the brain is likely a minimal source of EV proteins in urine ${ }^{46}$, this finding strengthens our hypothesis that urinary EV proteins and phosphoproteins are great candidates as potential biomarkers for PD. 
medRxiv preprint doi: https://doi.org/10.1101/2022.01.18.22269096; this version posted January 24, 2022. The copyright holder for this preprint (which was not certified by peer review) is the author/funder, who has granted medRxiv a license to display the preprint in perpetuity.

All rights reserved. No reuse allowed without permission.

The proteins and phosphoproteins identified must pass a rigorous statistical threshold and normalization to be statistically useful, as explained in more detail in the materials and methods section. We normalized both the proteome and phosphoproteome data based on internal standards. Figures $\mathbf{2 b}$ and $\mathbf{2 c}$ confirmed that the data had been effectively normalized with a coefficient of variation (CV) less than $20 \%$. We also identified the upregulated proteins and phosphoproteins in NMC, iPD, and LRRK2 PD groups against the controls.

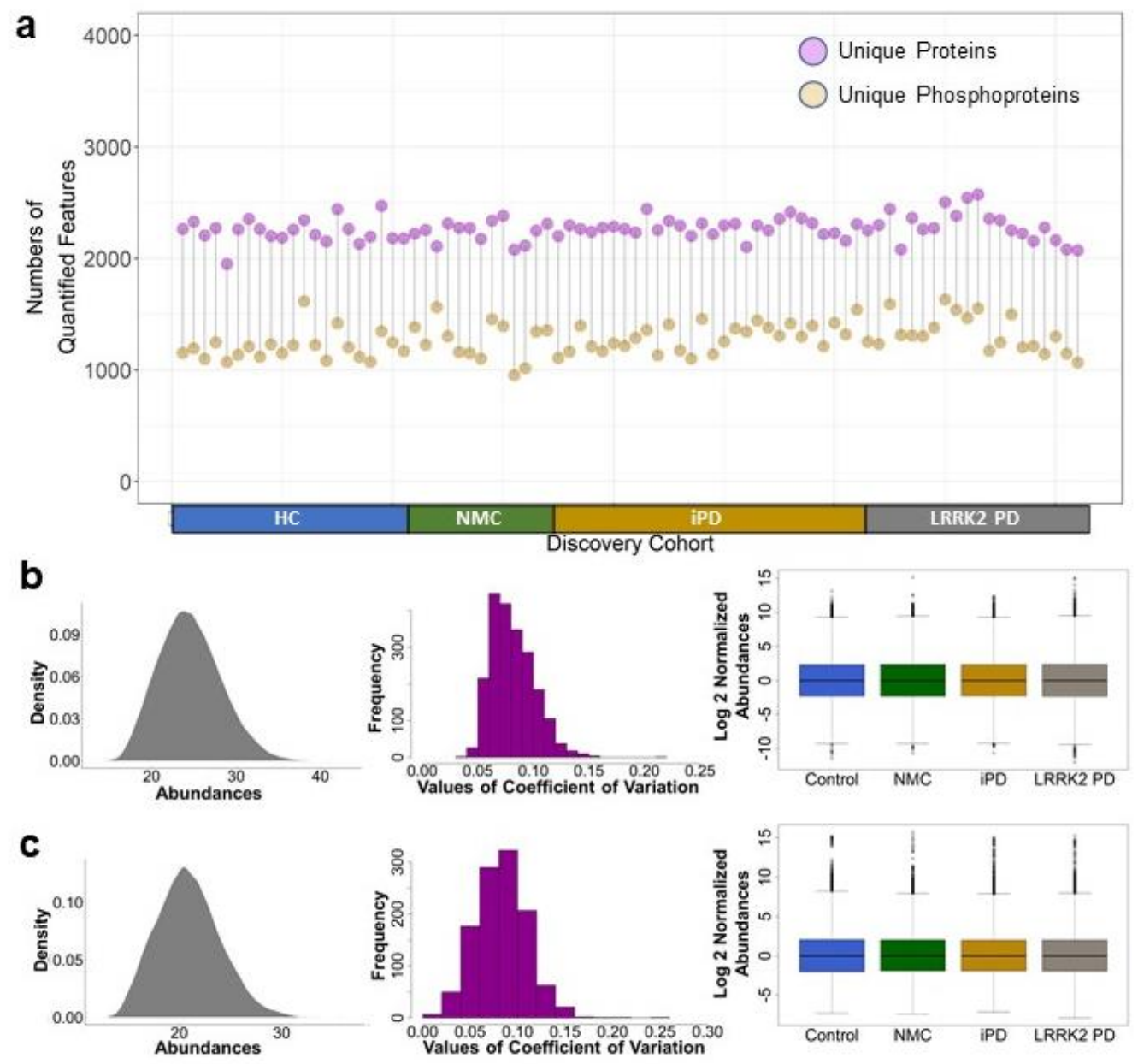

Figure 2. The summary of identification and quantification for all 82 patients. a) Cleveland Dot Plots for all quantified proteins and phosphoproteins. Both proteomic (b) and phosphoproteomic data (c) were normalized based on internal standards. Most quantified proteins and phosphoproteins had a CV of less than $20 \%$. Normalized quantified data in the training set were then analyzed using feature selection to find potential biomarkers for PD. 
medRxiv preprint doi: https://doi.org/10.1101/2022.01.18.22269096; this version posted January 24, 2022. The copyright holder for this preprint (which was not certified by peer review) is the author/funder, who has granted medRxiv a license to display the preprint in perpetuity.

All rights reserved. No reuse allowed without permission.

Functional annotation identifies inflammation, apoptosis, and $A \beta$ accumulation as the most prominent etiologies of PD in urine EVs.

We also performed gene ontology analysis to understand the correlation between all upregulated proteins and PD. We utilized Gene Ontology enRIchment anaLysis and visuaLizAtion tool (GOrilla) for biological process gene ontology analysis ${ }^{47}$. The upregulated proteins from each volcano plot were imputed as the target set, while all identified proteins in our results were used as the background set. The gene ontology was set with a threshold P-value of less than 10e-3. Select gene ontology results are shown in Supplementary Fig. 4.

As seen in Supplementary Figs. $\mathbf{4 b}$ and $\mathbf{4 c}$, the regulation of acute inflammatory response was enriched in both $\mathrm{PPD}$ and LRRK2 PD, supporting prior knowledge that PD has a strong established association with systemic inflammation. The abnormal glycation and glycosylation seem to be more common than previously thought in PD and may underlie inflammation and mitochondria-induced oxidative stress in a feed-forward mechanism ${ }^{48}$. Furthermore, since PD patients' CSF appears to have a specific metabolomic signature that reflects alterations in glycation or glycosylation, it was not surprising to discover that some biological process alterations involving glycosylation were enriched in urine $\mathrm{EVs}^{48,49}$. In NMC and LRRK2 PD, those enriched biological processes were glycoside catabolic process, protein Olinked glycosylation, protein glycosylation, glucosylceramide catabolic process, and glycosphingolipid catabolic process (Supplementary Figs. 4a, c). The pathway to degrade bradykinin (BK), a peptide that promotes inflammation and oxidative stress, was also enriched in $\mathrm{iPD}^{50}$ (Supplementary Fig. 4b). Even though there is no direct evidence of the kinin participation in PD, examining these peptides' roles in degenerative processes remains interesting. The degradation of BK might occur to counteract the overexpression of BK. Cytolysis, which is inhibited by various reducing agents, including dopamine, was also enriched in iPD ${ }^{51}$. The fact that dopamine production is diminished in PD supports the observed increase in cytolysis. Blood coagulation was enriched in LRRK2 PD, most likely due to the presence of amyloid formation in 
medRxiv preprint doi: https://doi.org/10.1101/2022.01.18.22269096; this version posted January 24, 2022. The copyright holder for this preprint (which was not certified by peer review) is the author/funder, who has granted medRxiv a license to display the preprint in perpetuity.

All rights reserved. No reuse allowed without permission.

plasma and profound ultrastructural changes to platelets ${ }^{4}$. The enrichment of fibrinolysis was also discovered in the LRRK2 PD population (Supplementary Fig. 4c). PD patients receiving antiparkinsonian drugs are often associated with blood coagulation and fibrinolysis abnormalities ${ }^{52}$.

Supplementary Fig. 4d comparison provides the most exciting discovery about the difference between NMC and LRRK2 PD gene ontology. In this evaluation, apoptotic DNA fragmentation and cellular response to amyloid-beta $(A \beta)$ were enriched in LRRK2 PD, supporting evidence that apoptosis and $A \beta$ accumulation are two of the most prominent etiologies $\mathrm{PD}^{53,54}$. Increasing experimental evidence has also indicated that the accumulation of misfolded or unfolded proteins results in endoplasmic reticulum stress, contributing to apoptosis or neuronal death $^{1,55}$.

\section{Diagnostic and prognostic panels correlate with disease progression.}

We investigated any correlations between the expression of these new potential biomarkers with age, gender, disease duration, MoCA score, and UPDRS-III score of the patients. There is increasing evidence that sex is an important factor in the development of PD ${ }^{56}$. In men, the risk of developing PD is nearly twice as high as in women. However, women have a higher mortality rate and faster disease progression ${ }^{57}$. MoCA was initially designed to evaluate mild cognitive impairment associated with $A D$ to assess memory, executive functions, and verbal fluency, among others, and can be applied in a short period of time ${ }^{58}$. The test has been used for the cognitive evaluation of patients with PD to identify cognitive deficits. MoCA scores range between 0 and 30, where a score of 26 or over is considered normal. UPDRS-III scoring method evaluates the patient's motor skills ranging from 0 to 108, with 108 being the worst.

We found that the expression levels of ENPEP, GDPD3, NAGA, NEDD4L, QPRT, and SCAMP3 proteins in urine EVs were significantly higher in males than in females (Supplementary Fig. 5a). There were positive correlations in the expression of FUT6 $\left(R^{2}=0.83\right.$, $P<0.05)$ and $\mathrm{HAO} 2\left(R^{2}=0.90, P<0.005\right)$ proteins with age in the female NMC group, as seen in 
medRxiv preprint doi: https://doi.org/10.1101/2022.01.18.22269096; this version posted January 24, 2022. The copyright holder for this preprint (which was not certified by peer review) is the author/funder, who has granted medRxiv a license to display the preprint in perpetuity.

All rights reserved. No reuse allowed without permission.

Supplementary Fig. 5b. Meanwhile, the expression of ALPL protein was negatively correlated with disease duration in the female iPD group (Supplementary Fig. 5c). Related to the MoCA scores in the male NMC group, we found a positive correlation in CAPN5 and HNRNPA1 proteins, and a negative correlation in ENPEP, GDPD3, and GPD1L proteins (Supplementary Fig. 5d). Additional significant correlations between protein abundance levels, MoCA scores, and gender are shown in Supplementary Fig. 5d.

At the phosphoprotein level, pNEU1 abundance was positively correlated with age in the female NMC group $\left(R^{2}=0.86, P<0.01\right)$ (Supplementary Fig. 6a). DTD1 phosphorylation was positively correlated with MoCA in the female NMC group (Supplementary Fig. 6b). pANXA11 and pHLA-B were negatively correlated with MoCA in the male NMC group, while there were positive correlations for CYSRT1, LTB4R, and TJP3 phosphoproteins. In addition, MoCA in female NMC was negatively correlated with the expression of CYSRT1 phosphoprotein. Lastly, the pLTBR4 level in the male LRRK2 PD group was positively correlated with MoCA.

Furthermore, we assessed the correlations of UPDRS-III scores with the protein and phosphoprotein intensities in IPD and LRRK2 PD patients versus those in the healthy individuals. We found several proteins and phosphoproteins depicted in Figure 3a and Supplementary Fig. 7 to be positively and negatively correlated with UPDRS-III, and many that are moderately correlated with the UPDRS-III $(0.5<$ Pearson correlation $<0.7)$. Lastly, Figure $\mathbf{3 b}$ shows three potential biomarkers, PEBP4, NEDD4L, and KLK6, with higher than 0.7 Pearson correlation scores, denoting a strong correlation with UPDRS-III. These correlation data need to be further validated, and their relevance to PD evaluated in a translational manner. 


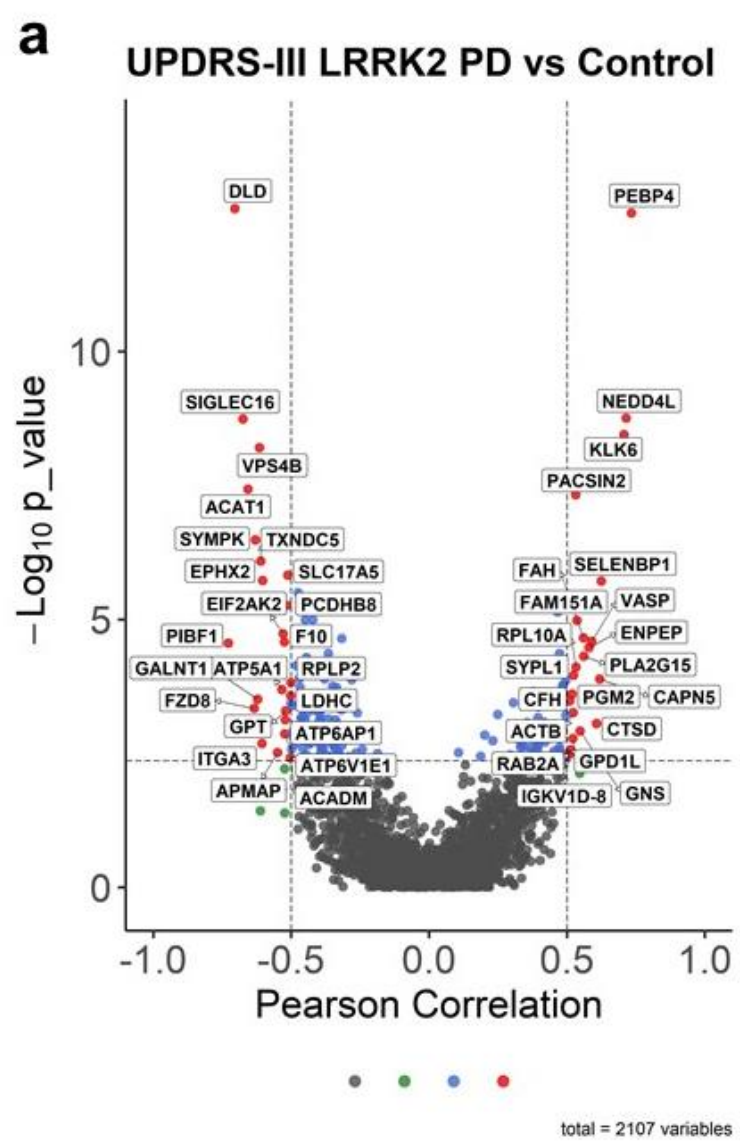

b
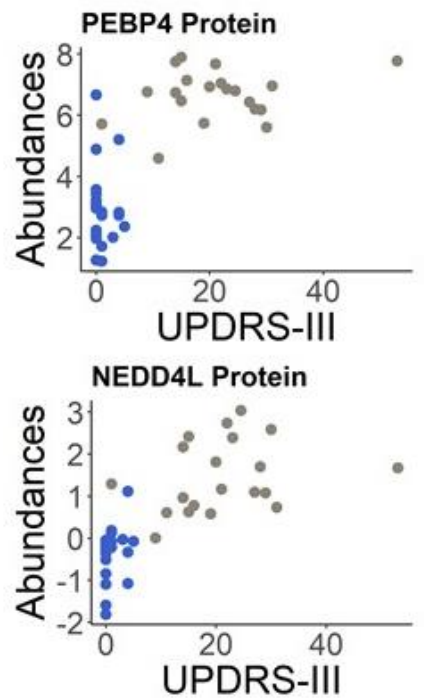

\section{KLK6 Protein}

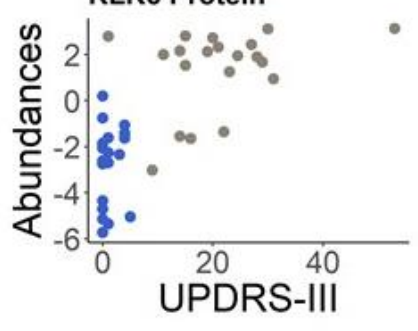

Figure 3. Correlations with clinical parameter, UPDRS-III. a) Pearson correlation scores and associated $P$-values [$\left.\log _{10}\right]$ of all protein intensities with the UPDRS-III score. LRRK2 PD patients were included. Significantly correlated proteins with an FDR of $5 \%$ after Benjamin-Hochberg correction are labeled. b) The scatterplots of three biomarkers with strong Pearson correlation scores $(>0.7)$.

\section{Disease-related EV protein and phosphoprotein biomarkers are prominently involved in the autophagy pathway.}

As potential disease markers, HNRNPA1, IDE, and STK11 proteins are shown to be involved in certain pathways that are important in PD progressions, such as protein targeting to peroxisome, AMPK signaling pathway, leukocyte activation, and mRNA splicing (Figure 4a). These markers also interact closely with PRKACA, VDAC1, VDAC2, and VDAC3, known to be PD related ${ }^{59}$. Moreover, five disease markers, PCSK1N, HNRNPA1, FUT6, pPLA2G4A, and pLTB4R, are known to be involved in such important PD pathways as neuronal cell death, 
medRxiv preprint doi: https://doi.org/10.1101/2022.01.18.22269096; this version posted January 24, 2022. The copyright holder for this preprint (which was not certified by peer review) is the author/funder, who has granted medRxiv a license to display the preprint in perpetuity.

All rights reserved. No reuse allowed without permission.

neuroinflammation, autophagy, and formation of amyloid fibrils (Figure 4b). From the Ingenuity Pathway Analysis (IPA), the upregulation of IDE leads to neuronal cell death activation, while the upregulation of STK11 indirectly leads to autophagy activation. PLA2G4A and LTB4R phosphoproteins were shown to be involved in downstream GPCRs and MAPK signaling pathways (Supplementary Fig. 8a). Meanwhile, the presence of NEU1, a lysosomal enzyme and a disease marker, supports the emerging concept that PD is a lysosomal disorder ${ }^{60}$ (Supplementary Fig. 8b). Furthermore, the overexpression of PLA2G4A, LTB4R, and NEU phosphoproteins can trigger the autophagy pathway, one of the hallmark pathways in PD (Supplementary Fig. 8c). Interestingly, NEU1 showed two contradicting downstream effects. The overexpression of low-density lipoprotein (LDL)-cholesterol by NEU1 inhibited autophagy. On the other hand, the inhibited expression of high-density lipoprotein (HDL)-cholesterol by NEU1 triggered autophagy. In Supplementary Fig. 8c, PLA2G4A is shown to indirectly activate autophagy, supporting the fact that PLA2G4A activation leads to the impairment of autophagy flux by directly increasing lysosomal membrane permeabilization (LMP) $)^{61}$. The interactions of LTB4R/RAC1/PAK1/p38 MAPK are also known to activate autophagy.

Additionally, Figure 4c depicts the pathways on how risk markers, ALDH1L1, pRECK, and pFKBP15 proteins, could trigger PD. The upregulated MAP2K1 causes the upregulation of ALDH1L1 and MAOB, which further activates PD. Selegiline, an inhibitor of MAOB protein, has been approved by the FDA to treat PD. ALDH1L1 has been developed as one of the astrocyte markers and is homogenously expressed throughout the brain ${ }^{62}$. From our study, this novel marker by itself appears to be sufficient enough to act as the risk biomarker for PD. The upregulation of APOE inhibits the expression of ADAM10; consequently, pFKBP15 is overexpressed, and EGFR expression is downregulated.

Meanwhile, pRECK overexpression also inhibits EGFR expression. EGFR downregulation has been shown in postmortem brains of patients ${ }^{63}$. HNF4A can inhibit SPP1 and activate APOM, which leads to HDL-cholesterol activation. High-plasma HDL is associated with increased PD risk 
medRxiv preprint doi: https://doi.org/10.1101/2022.01.18.22269096; this version posted January 24, 2022. The copyright holder for this preprint (which was not certified by peer review) is the author/funder, who has granted medRxiv a license to display the preprint in perpetuity.

All rights reserved. No reuse allowed without permission.

and duration ${ }^{64,65}$. The overexpressed ALPL also inhibits SPP1, a glycosylated phosphoprotein expressed in neurons, and appears to play the role of a double-edged sword in neurodegenerative diseases $^{66}$. SPP1 may be toxic to neurons, lead to cell death in some cases, and have potent neuroprotective effects in others ${ }^{67}$.
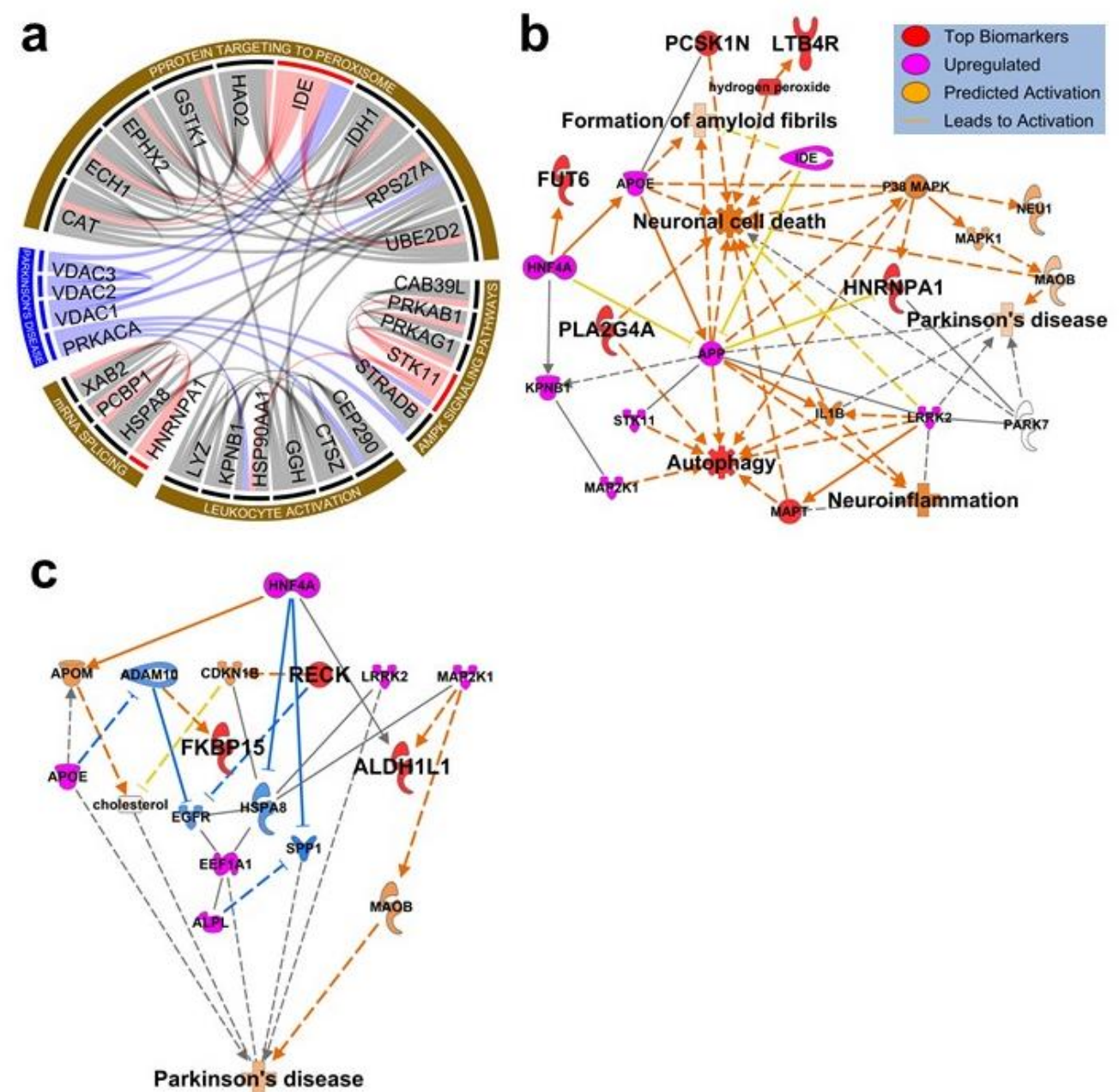

Figure 4. Protein and phosphoprotein biomarker network and pathway analysis. A circos plot (a) and the IPA pathway analysis of the protein and phosphoprotein disease markers (b) and risk markers (c). see Supplementary Fig. 11 for a complete figure legend.

Top disease and risk biomarkers were selected and evaluated using ten-fold crossvalidation 
medRxiv preprint doi: https://doi.org/10.1101/2022.01.18.22269096; this version posted January 24, 2022. The copyright holder for this preprint (which was not certified by peer review) is the author/funder, who has granted medRxiv a license to display the preprint in perpetuity.

All rights reserved. No reuse allowed without permission.

The discovery experiment, which included samples from 21 healthy individuals (control), 13 healthy individuals with G2019S mutation in the LRRK2 gene (non-manifesting carrier/NMC), 28 PD individuals without G2019S mutation (idiopathic PD/iPD), and 20 PD individuals with G2019S mutation (LRRK2 PD), were randomly divided into two groups: 70\% training set and 30\% test set for biomarker selection and predictive ability estimation (Figure 1). We developed and employed a robust bioinformatics workflow to identify potential PD biomarkers. The median normalization was performed on the training set so that all abundances in the four groups had the same median. After passing thresholds and robust normalizations, we obtained and quantified a total of 2,128 qualified unique proteins and 1,154 qualified unique phosphoproteins.

From these curated training data, we generated six volcano plots for comparisons between NMC, iPD, and LRRK2 PD groups against the control samples (Supplementary Fig. 9a and 9b). The upregulated proteins and phosphoproteins were overlapped in Venn diagrams. As mentioned previously, we investigated potential biomarkers in two different groups, identified as disease markers and risk markers. We denoted disease markers as upregulated in PD regardless of the LRRK2-G2019S mutation. Risk markers were labeled as upregulated in both NMC and iPD groups. A single protein biomarker might be involved in several already known diseases. To offer a better diagnostic value, we proposed to quantify a set of several biomarkers rather than a single diagnostic protein.

We first performed feature selection to select the top disease and risk biomarkers. Instead of using a simple one-shot feature selection technique that usually yields a sub-optimal solution, we used a two-step feature selection process that generates better performance: backward feature elimination followed by exhaustive feature selection ${ }^{68}$. We deployed backward feature elimination which removes, one feature at a time, those features that do not have a significant effect on the dependent variable or prediction of output. Then, we deployed exhaustive feature selection to find the best performing feature subset by searching across all possible feature combinations (a brute-force method), until the desired number of features is left. Specifically, this 
medRxiv preprint doi: https://doi.org/10.1101/2022.01.18.22269096; this version posted January 24, 2022. The copyright holder for this preprint (which was not certified by peer review) is the author/funder, who has granted medRxiv a license to display the preprint in perpetuity.

All rights reserved. No reuse allowed without permission.

number is determined by observing the increase in performance (accuracy) with the increase in the number of final selected features (in which it is diminishing return). By utilizing this two-layer method, we could identify the top 6 disease biomarkers and 3 risk biomarkers. The final selected markers are shown in Figure $\mathbf{5 a}$ and $\mathbf{5 b}$ and listed in Figure $\mathbf{5 c}$. The violin plots of the selected disease and risk biomarkers are shown in Figures $\mathbf{5 d}$ and $\mathbf{5 e}$, respectively (see Supplementary Fig. 10 for additional top biomarkers). After discovering the top disease and risk biomarkers, we optimized our hyperparameters and trained our model using the random forest classifier. Lastly, we trained our model by utilizing the ten-fold cross-validation.

\section{a}

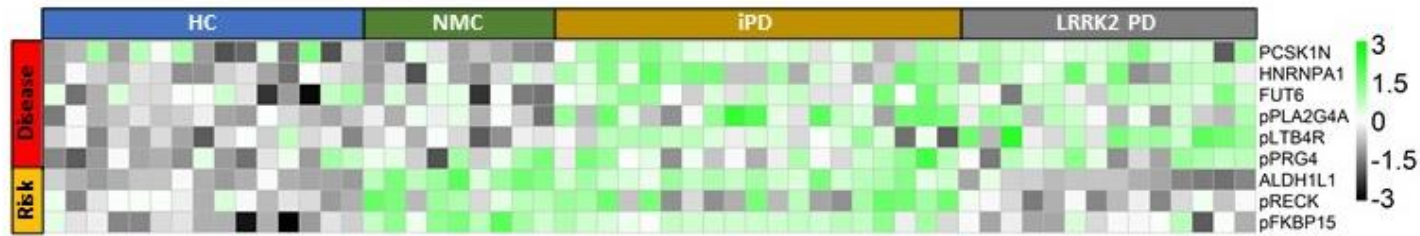

b

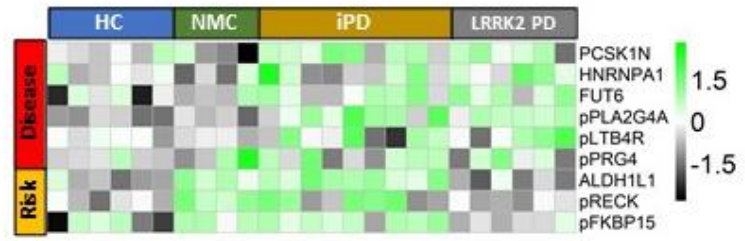

\begin{tabular}{|l|l|l|}
\cline { 2 - 3 } C & Disease & Risk \\
Biomarkers & Biomarkers \\
\hline PCSK1N & ALDH1L1 \\
HNRNPA1 & pRECK \\
FUT6 & pFKBP15 \\
pPLA2G4A & \\
pLTB4R & \\
pPRG4 & \\
\hline
\end{tabular}
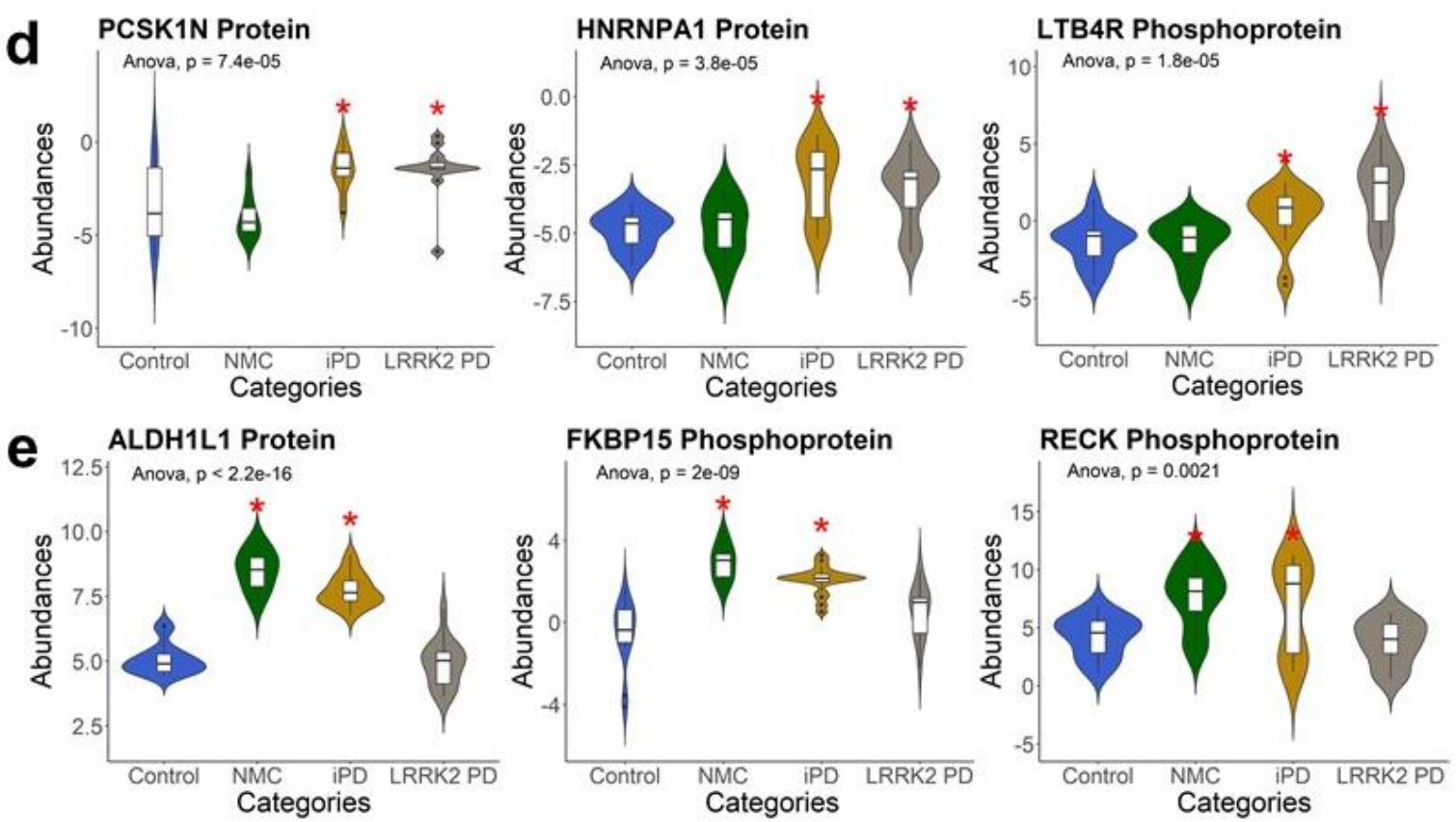
medRxiv preprint doi: https://doi.org/10.1101/2022.01.18.22269096; this version posted January 24, 2022. The copyright holder for this preprint (which was not certified by peer review) is the author/funder, who has granted medRxiv a license to display the preprint in perpetuity.

All rights reserved. No reuse allowed without permission.

Figure 5. The selected top disease and risk biomarkers acquired from the training set. a) The training set's heatmap of top potential protein and phosphoprotein biomarkers. b) The heatmap of top potential protein and phosphoprotein biomarkers in the test set. c) The table summary of the top disease and risk biomarkers. Violin plots of the statistically upregulated proteins and phosphoproteins from the training set in (d) PD regardless of the $L R R K 2-$ G2019S mutation (disease markers) and (e) in both NMC and iPD groups (risk markers) (see Supplementary Fig. 10 for additional biomarkers).

\section{Disease biomarkers were substantiated using classification models, PRM-MS targeted mass spectrometry, and Western blot experiments.}

After the careful feature selection and hyperparameters as described above, we tested our constructed model using accuracy scores, confusion matrixes, and receiver operating characteristic $(\mathrm{ROC})$ curves, as depicted in Figure 6. A confusion matrix evaluates one classifier with a fixed threshold, while the ROC evaluates that classifier over all possible thresholds. The area under the ROC curve (AUC) provides the performance measurement across the classification threshold. A higher true positive percentage and a lower false-positive percentage will produce better AUC results. Normally, in the medical field, an AUC of $70-80 \%$ is considered acceptable, $80-90 \%$ is considered good, and $90-100 \%$ is considered excellent. For example, the AUC for the top six disease biomarkers is $95.9 \%$, with $85.52 \%$ confusion matrix accuracy (Figure 6a and 6c). This panel would result in a 95.9\% likelihood that the doctor will correctly distinguish a PD patient from a healthy patient based on finding the six biomarkers at an elevated level in the urinary EVs. Furthermore, we found that using all three protein and phosphoprotein risk biomarkers resulted in an AUC of $99.80 \%$ with $95.56 \%$ accuracy for the confusion matrix (Figure $6 b$ and $6 d$ ). Certainly, these findings need to be verified with a much more expanded validation cohort. 
medRxiv preprint doi: https://doi.org/10.1101/2022.01.18.22269096; this version posted January 24, 2022. The copyright holder for this preprint (which was not certified by peer review) is the author/funder, who has granted medRxiv a license to display the preprint in perpetuity.

All rights reserved. No reuse allowed without permission.

a

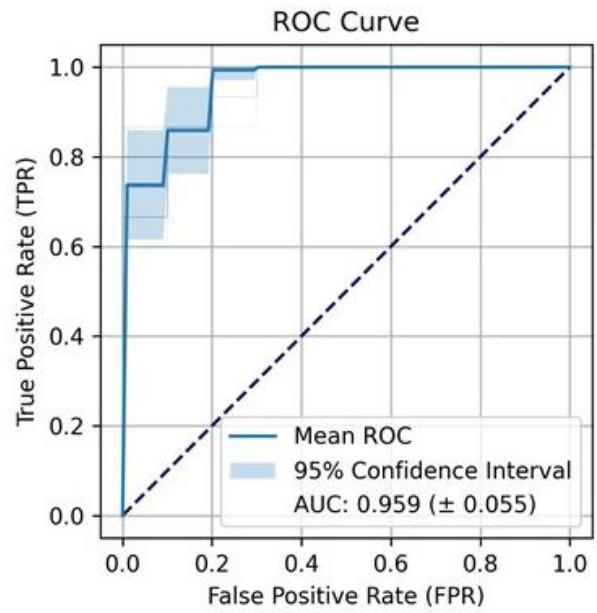

b

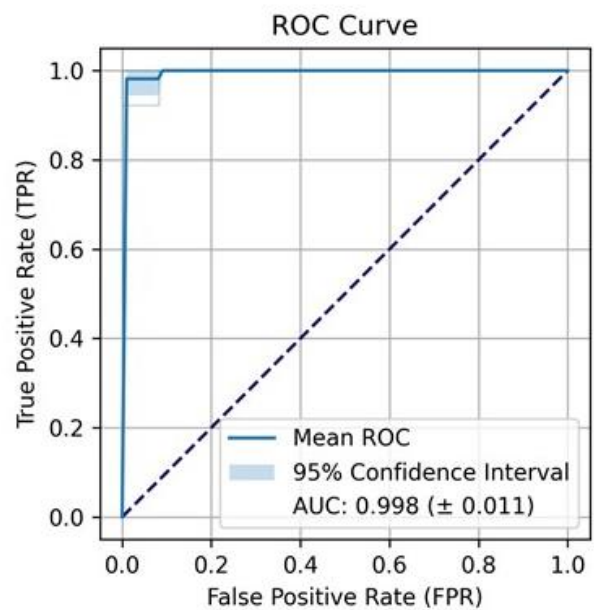

C

$\begin{array}{ll}\text { Accuracy } & =85.52 \%( \pm 9.75 \%) \\ \text { Sensitivity } & =0.80( \pm 0.11) \\ \text { Specificity } & =0.89( \pm 0.09) \\ \text { PPV } & =0.84( \pm 0.10) \\ \text { NPV } & =0.87( \pm 0.09)\end{array}$
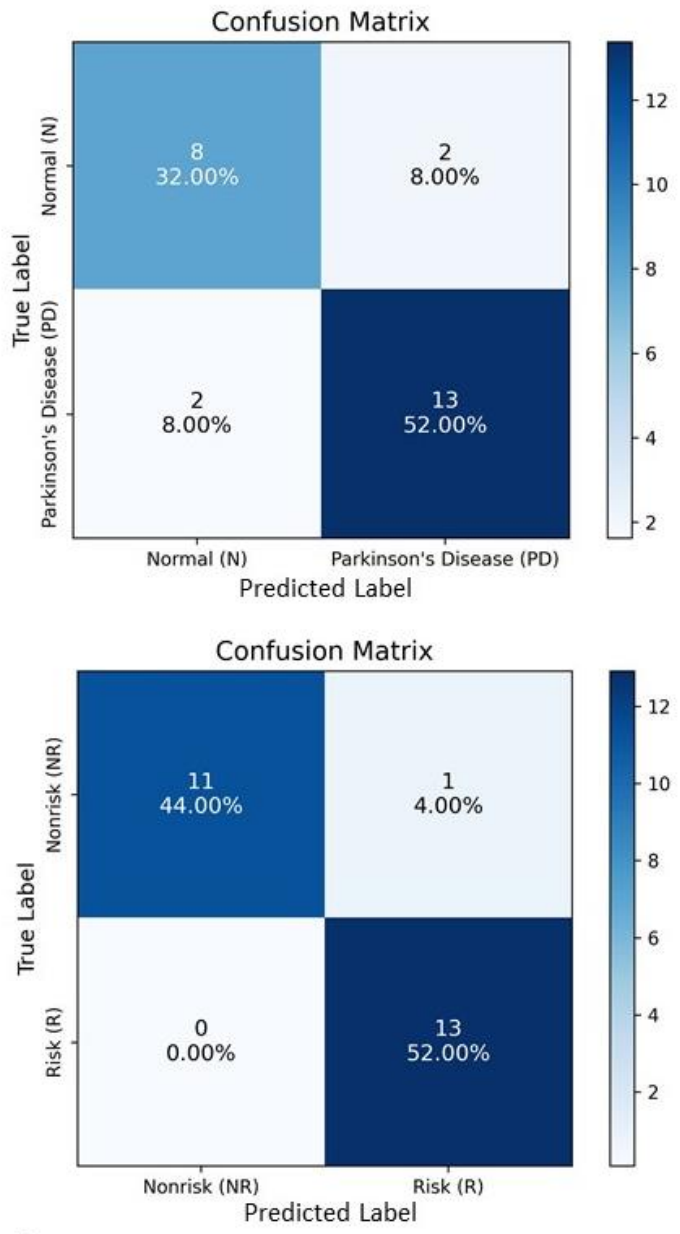

d

\begin{tabular}{ll|} 
Accuracy & $=96.56 \%( \pm 5.05 \%)$ \\
Sensitivity & $=0.94( \pm 0.07)$ \\
Specificity & $=0.99( \pm 0.02)$ \\
PPV & $=0.99( \pm 0.02)$ \\
NPV & $=0.94( \pm 0.06)$
\end{tabular}

Figure 6. Unbiased estimation of predictive ability of urinary proteomes and phosphoproteomes on the test set. Receiver operating characteristic (ROC) curves and the confusion matrixes for the Random Forest Classifier model to classify (a) Parkinson's Disease (PD) vs. Normal (N) individuals and (b) Risk (R) vs. Nonrisk (NR) individuals. The dotted diagonal line indicates random performance, and the light blue area represents the $95 \%$ confidence interval. The accuracy, sensitivity, specificity, positive predictive value (PPV), and negative predictive value (NPV) scores with their $95 \%$ confidence intervals are shown for both (c) the PD vs. $N$ and (d) the R vs. NR.

Parallel Reaction Monitoring-Mass Spectrometry (PRM-MS) and Western blot are both commonly used for the initial validation of potential biomarkers. We selected several of our top 
disease biomarkers and urinary exosome markers for further validation. Quantitative assays based on PRM-MS were performed with a new set of urine EV samples from 28 patients with PD and 11 healthy individuals. All of the samples used in the validation experiments came from a new cohort of patients. Two disease markers, HNRNPA1 and HAO2, were observed to be significantly upregulated in patients with PD compared to healthy individuals (Figure 7a).

Interestingly, FN1, one of the urinary exosome markers, was also upregulated in PD patients $(P<0.01)$. We further performed immunoassay with this new cohort of urine EV samples from 10 patients with PD and 10 healthy individuals. Three disease markers, HNRNPA1, PCSK1N, and STK11, were noticeably upregulated in patients with PD compared to healthy individuals (Figure 7b, see Supplementary Fig. 11 for the original Western blot images).

\section{a Parallel Reaction Monitoring (PRM-MS)}
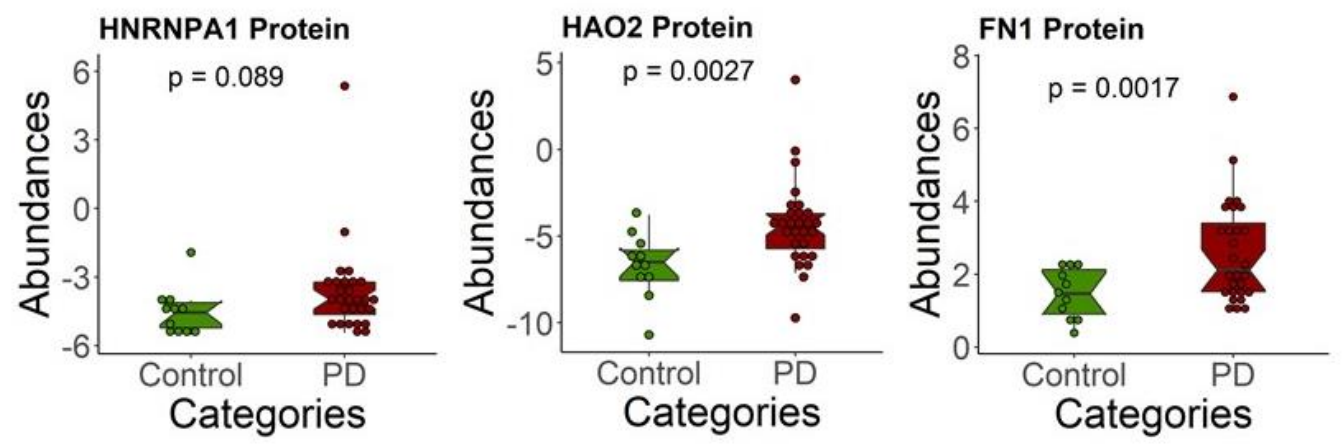

b

Western Blot
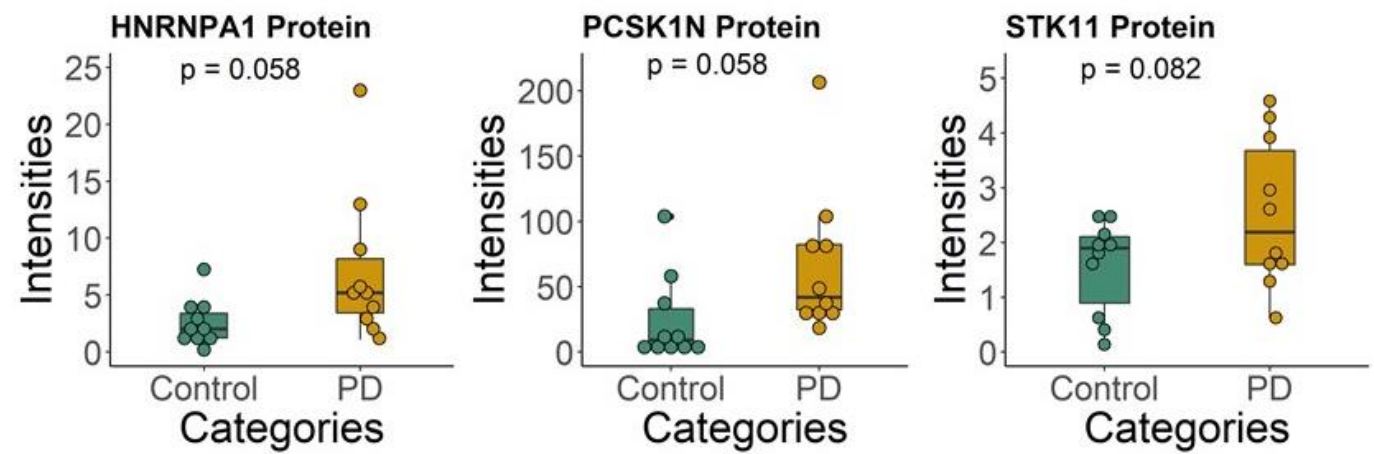

Figure 7. Targeted quantitation of potential disease biomarkers. a) One top disease biomarker, HNRNPA1, was validated in 28 patients with $P D$ and 11 healthy individuals, using $P R M-M S(P<0.1)$. HAO2 and FN1 were also significantly upregulated in PD $(P<0.01)$. b) Two top disease biomarkers, HNRNPA1 and PCSK1N, and a potential 
medRxiv preprint doi: https://doi.org/10.1101/2022.01.18.22269096; this version posted January 24, 2022. The copyright holder for this preprint (which was not certified by peer review) is the author/funder, who has granted medRxiv a license to display the preprint in perpetuity.

All rights reserved. No reuse allowed without permission.

disease biomarker, STK11, were validated in 10 patients with PD and 10 healthy individuals using Western blot $(\mathrm{P}<$ 0.1). The student's t-test calculated all $P$ values.

\section{LRRK2 and its Rab Substrates Signaling are altered but not significant PD biomarkers.}

Finally, we also focused our efforts on the direct LRRK2 activation in these urine EV samples in addition to new biomarker discovery. LRRK2 is known to phosphorylate a subgroup of Rab proteins, and LRRK2-G2019S mutation has been previously shown to increase the phosphorylation of its Rab substrates ${ }^{16}$. Rab proteins are master regulators of membrane trafficking, orchestrating vesicle formation and vesicle movement along actin and tubulin networks, as well as membrane docking and fusion - all critical aspects of autophagy and lysosome biology ${ }^{16}$. First, we performed Western blot analyses of all 82 urine samples, quantifying CD9 (common exosome marker), LRRK2, and pSer1292-LRRK2 signal in the EVs captured by EVtrap (Supplementary Fig. 12a). pSer1292, a LRRK2 autophosphorylation site, indirectly reflects LRRK2 activation ${ }^{69}$. We normalized and compared the signal between all samples using a recombinant autophosphorylated LRRK2 protein as an internal standard ${ }^{39}$. As expected, the normalized CD9 signal did not show a significant difference between the sample groups (Supplementary Fig. 12b), while the expression of LRRK2 in LRRK2 PD was significantly higher than in the control samples $(\mathrm{P}=0.028)$. Unfortunately, it was challenging to detect the pSer1292LRRK2 signal in most samples, caused by a meager amount of this modified protein in the samples and/or a lower antibody sensitivity. Due to undetectable signals in most samples, we did not find any significant difference in the pSer1292-LRRK2 phosphorylation level itself (Supplementary Fig. 12b). We also compared the Western blot quantitative result with the mass spectrometry data (Supplementary Fig. 12c). While not all of the differences observed in these Western Blot and mass spectrometry experiments showed statistically significant changes, there was an apparent trend of higher LRRK2 signal in the G2019S groups (NMC and LRRK2 PD) in both the Western blot and mass spectrometry data. Interestingly, the LRRK2 overall 
medRxiv preprint doi: https://doi.org/10.1101/2022.01.18.22269096; this version posted January 24, 2022. The copyright holder for this preprint (which was not certified by peer review) is the author/funder, who has granted medRxiv a license to display the preprint in perpetuity.

All rights reserved. No reuse allowed without permission.

phosphorylation level (sites other than Ser1292) is lower in NMC and significantly lower in LRRK2 PD than in the control group. Indeed, the low level of phosphorylated LRRK2 in EVs might explain why it was challenging to detect pSer1292-LRRK2 signals in the Western Blot.

From the urine EV LC-MS analyses, we identified 34 Rab GTPases, 12 of which are known LRRK2 substrates, and eight phosphorylated Rab GTPases (Supplementary Table. 1). After indepth statistical normalization and qualification, we quantified 15 Rab GTPases (10 LRRK2 substrates) and four phosphorylated Rab GTPases. We observed that Rab2A $(\mathrm{P}<0.003)$ and Rab10 ( $P=0.037)$ were significantly upregulated in LRRK2 PD compared to the control samples (Supplementary Fig. 13a). Rab2A's involvement in retrograde trafficking and particle recycling from Golgi back to the endoplasmic reticulum (ER) shows the role of this protein in the organellar homeostasis pathway to prevent misfolded proteins from entering the Golgi apparatus ${ }^{6}$. Thus, the upregulation of Rab2A in LRRK2 PD, which may promote retrograde trafficking machinery, may be the a-syn aggregation stress response.

Rab10 is a well-known substrate of LRRK2, and in vitro assays suggested that PD-related neurodegeneration may start by LRRK2-G2019S increasing phosphorylation of Rab10 ${ }^{70}$. It is also known that Rab10 is involved in LRRK2 and other Rabs relocalization ${ }^{71}$. Therefore, it is not surprising that Rab10 was present at higher levels in the LRRK2 PD group EVs (Supplementary Fig. 13a). Interestingly, Rab17 protein was qualified to be one of our progression markers, although currently, the role of Rab17 in PD progression is not fully understood. At the phosphoprotein level, only Rab12 $(\mathrm{P}<0.005)$ was significantly upregulated in LRRK2 PD (Supplementary Fig. 13a). Rab12 is a LRRK2 endogenous substrate that plays a role in endosomal lysosome sorting, degradation, and autophagy ${ }^{71}$.

We also investigated the correlation of the identified Rab GTPase expression levels with age, gender, disease duration, and MoCA scores with the new biomarkers. As seen in Supplementary Figure 13b, the expression of Rab1A protein in females was significantly higher than in males with $\mathrm{P}<1 \mathrm{e}-12$. In contrast, Rab1B $(\mathrm{P}<0.0005)$, Rab3D $(\mathrm{P}<0.005)$, and Rab7A 
medRxiv preprint doi: https://doi.org/10.1101/2022.01.18.22269096; this version posted January 24, 2022. The copyright holder for this preprint (which was not certified by peer review) is the author/funder, who has granted medRxiv a license to display the preprint in perpetuity.

All rights reserved. No reuse allowed without permission.

$(\mathrm{P}<0.05)$ were expressed at higher levels in males than females. We also observed that the expression level of Rab2A protein in female iPD individuals was positively correlated with age $\left(R^{2}=0.68, P<0.001\right)$ (Supplementary Fig. 13c). Meanwhile, the expression of Rab17 protein in female iPD individuals was positively correlated with MoCA $\left(R^{2}=0.63, P<0.005\right)$ (Supplementary Fig. 13d). As noted before, these correlations need to be reproduced and evaluated further to better understand their significance.

\section{Discussion}

Mass spectrometry (MS)-based biofluid proteome analysis and quantitation have recently gained renewed interest and excitement in disease profiling efforts. The approach offers immeasurable potential for innovative biomarker discovery. However, successful translation from MS data to human disease profiling remains limited. This limitation is partly due to the complexity of biofluids, which have a very large dynamic range and are typically dominated by a few highly abundant proteins. To date, scientists have been concentrating on finding PD biomarkers in biofluids such as CSF, plasma, and urine without paying much attention to the importance of EVs as a potential source of biomarkers ${ }^{72}$. Here, we report in-depth analyses of proteome and phosphoproteome in urinary EVs and demonstrate the viability of developing proteins and phosphoproteins as potential disease biomarkers. We present an MS-based strategy that includes isolating EV particles from human urine utilizing EVtrap, enrichment of EV phosphopeptides, in-depth LC/MS analysis, and robust bioinformatics evaluation for biomarker discovery and qualitative verification. We analyzed EV samples from patients with LRRK2G2019S mutation (NMC), idiopathic-PD (iPD), and LRRK2 PD compared to healthy individuals to identify candidate disease and risk biomarkers.

In total, we discovered two panels of high-confidence biomarkers, which were substantiated using ROC, machine learning, and in-depth network analysis. Several disease biomarkers have also been validated using targeted approaches - PRM and Western blot (Figures 7a and 7b). The disease biomarkers could be employed for PD detection in a non- 
medRxiv preprint doi: https://doi.org/10.1101/2022.01.18.22269096; this version posted January 24, 2022. The copyright holder for this preprint (which was not certified by peer review) is the author/funder, who has granted medRxiv a license to display the preprint in perpetuity.

All rights reserved. No reuse allowed without permission.

invasive way using a simple urine collection. The risk markers can be further investigated for early-onset PD detection and prognosis. Together, the extensive data on these potential biomarkers might serve as a future of PD detection in a non-invasive and more cost-effective manner and as a resource to the research community for further studies. In other words, this platform represents a foundational resource for the emerging field of accurate and reproducible proteomic biomarker discovery. We also showed that some biomarkers sustained positive or negative correlations with gender, age, disease duration, MoCA, and UPDRS-III. However, we need to emphasize that these correlations do not automatically mean causation. Some relevant correlations should be studied further to provide more information about the corresponding biomarkers. Furthermore, the emerging system/network analysis has revolutionized novel mechanism discovery and promising drug targets. Our network analysis of the gene expression involving these potential biomarkers has revealed the connections between our biomarkers and critical pathways that could lead to PD development.

We also directed significant attention to LRRK2 kinase and its Rab substrate proteins. This project involved two groups of patients with LRRK2-G2019S mutation, a feature present in some PD patients. However, it is known that the mutated LRRK2 does not necessarily lead to PD onset, and many individuals live with this mutation without developing Parkinson's disease. This study found a minor increase in LRRK2 protein amount and its overall phosphorylation level in PD patients' urine EVs (Supplementary Fig. 12). Similarly, a few select Rab proteins showed an increased EV signal in total protein amount and phosphorylation level in PD cases (Rab2A, Rab10, Rab12; Supplementary Fig. 13). However, none were selected as the optimal potential biomarkers for PD diagnosis or prognosis. This finding further underscores the reality that Parkinson's disease is highly complicated, with multiple signaling pathways involved in its pathology. While LRRK2 kinase is known to be involved in PD progression, detecting LRRK2 and its direct substrates may not provide sufficient differentiation between cases. As carried out here, a more global analysis is needed to determine the most statistically significant biomarkers that 
medRxiv preprint doi: https://doi.org/10.1101/2022.01.18.22269096; this version posted January 24, 2022. The copyright holder for this preprint (which was not certified by peer review) is the author/funder, who has granted medRxiv a license to display the preprint in perpetuity.

All rights reserved. No reuse allowed without permission.

may or may not be directly influenced by LRRK2 activity. We advocate that such a comprehensive analysis with highly stringent bioinformatics data validation gives us the best opportunity to discover the most optimal differentiating markers.

In summary, we have developed several comprehensive biomarker panels of proteins and phosphoproteins in urinary extracellular vesicles as biosignatures for Parkinson's disease diagnosis and prognosis. The study highlights our ability to isolate and identify thousands of unique proteins and phosphoproteins from relatively small volumes of urine samples by utilizing the EVtrap EV enrichment approach. These findings further validate the underlying principle that this strategy could be valuable for exploring existing resources in a wide range of diseases. Finally, we expect our immediate results, followed by extensive evaluation and validation of the new markers in the clinical setting, could improve these patients' medical outcomes and quality of life.

\section{Methods}

\section{Sample Collection}

All 82 urine samples used in the discovery LC-MS study and 59 urine samples used in the validation experiments were collected at Columbia University Irving Medical Center (CUIMC) and sent to our lab blindly. The samples were collected from March 2016 to April 2017 under a Michael J. Fox Foundation (MJFF)-funded LRRK2 biomarker project ${ }^{27}$. Each sample has been uniquely curated for LRRK2 genotype and PD activity effects. For the initial comprehensive discovery experiments, the urine samples were collected from 21 healthy individuals (Control), 13 healthy individuals with G2019S mutation (non-Manifesting Carrier/NMC), 28 PD individuals without G2019S mutation (idiopathic-PD/iPD), and 20 PD individuals with G2019S mutation (LRRK2 PD). The 59 urine samples used for the validation experiments were classified as 38 patients with PD and 21 healthy individuals without genetic differentiation. All 141 samples were processed separately by implementing the statistical principles in experimental designs, including replication, randomization, and blocking when applicable ${ }^{73}$. 
medRxiv preprint doi: https://doi.org/10.1101/2022.01.18.22269096; this version posted January 24, 2022. The copyright holder for this preprint (which was not certified by peer review) is the author/funder, who has granted medRxiv a license to display the preprint in perpetuity.

All rights reserved. No reuse allowed without permission.

\section{EV Isolation by EVtrap}

For each urine sample, approximately $15-20 \mathrm{~mL}$ was utilized for EV enrichment by EVtrap. Before the EVtrap capture, the urine volume was normalized based on the creatinine levels, a normalizer we found to be optimal for EV studies. The EVtrap beads were provided by Tymora Analytical and were utilized as described previously ${ }^{44}$. The frozen urine samples were thawed in a $37^{\circ} \mathrm{C}$ water bath. The samples were then centrifuged at 2,500 $\mathrm{xg}$ for $10 \mathrm{~min}$ to remove cell debris and large apoptotic bodies and diluted with EVtrap loading buffer in a 1:10 v/v ratio. The magnetic EVtrap beads were added directly to the diluted at a ratio of $20 \mathrm{uL}$ EVtrap beads per $1 \mathrm{~mL}$ urine. The mixture was incubated for 1 hour by end-over-end rotation, and the supernatant was removed using a magnetic separator rack, the beads were washed with PBS, and the EVs were eluted by a 10 min incubation with $100 \mathrm{mM}$ triethylamine (TEA, Millipore-Sigma). The eluted samples were dried entirely in a vacuum centrifuge. For Western blot analysis, the dried EV samples were lysed directly in LDS buffer (lower volumes of urine $(\sim 0.5-2 \mathrm{~mL})$ were used for Western blot experiments).

\section{EV Isolation by Differential Ultracentrifugation (UC)}

Urine samples $(\sim 1-2 \mathrm{~mL})$ were centrifuged at $10,000 \times \mathrm{g}$ at $4^{\circ} \mathrm{C}$ for $1 \mathrm{~h}$. Supernatants were further centrifuged at an ultra-high speed of 100,000 $\times \mathrm{g}$ (Optima MAX-XP Ultracentrifuge, Beckman Coulter) at $4^{\circ} \mathrm{C}$ for $2 \mathrm{hrs}$. Pellets were washed with $1 \times$ PBS and centrifuged at $100,000 \times \mathrm{g}$ for 2 hrs again. Collected pellets were lysed directly in LDS buffer for Western blot analysis.

\section{Western Blot Experiments}

A small percentage (approximately $0.5 \mathrm{~mL}$ urine sample equivalent for CD9, $1 \mathrm{~mL}$ for LRRK2, and $2 \mathrm{~mL}$ for pSer1292-LRRK2) of each purified EV sample was incubated for $10 \mathrm{~min}$ at $95^{\circ} \mathrm{C}$ in LDS sample buffer. The equivalent volume of each sample aliquot was loaded and separated on an SDS-PAGE gel (NuPAGE 4-12\% Bis-Tris Gel, Thermo Fisher Scientific). Afterward, the proteins were transferred onto a low-fluorescence PVDF membrane (Millipore-Sigma), and the membrane was blocked with 1\% BSA in TBST for $1 \mathrm{hr}$. The membranes were then incubated with rabbit anti-CD9 (clone D3H4P; Cell Signaling Technology) at 1:5,000 ratio, or anti-LRRK2 (clone 
medRxiv preprint doi: https://doi.org/10.1101/2022.01.18.22269096; this version posted January 24, 2022. The copyright holder for this preprint (which was not certified by peer review) is the author/funder, who has granted medRxiv a license to display the preprint in perpetuity.

All rights reserved. No reuse allowed without permission.

MJFF2 (c41-2); Abcam) at 1;1,000 ratio, or anti-pSer1292-LRRK2 (clone MJFR-19-7-8; Abcam) at 1:500 ratio overnight in 1\% BSA in TBST (3\% BSA in TBST was used for anti-pSer1292LRRK2). For the secondary antibody visualization, Goat anti-Rabbit Alexa-Fluor $800 \mathrm{~nm}$ (Thermo Fisher Scientific) was used to bind the primary antibodies and incubated for $1 \mathrm{hr}$ in $1 \%$ BSA in TBST. Lastly, the membrane was scanned by Odyssey near-infrared scanner (Licor) for signal detection and quantitation. A total of 8 blots were used for each protein target detection. We loaded internal standards at an identical concentration in each blot to normalize the signal between the samples and the blots. For CD9 relative quantitation, we extracted EVs from a mixture of several unrelated samples as an internal control added as a separate lane into each gel to enable gel-to-gel relative quantitation of the signal. For the relative quantitation of LRRK2, we used the same amount of the recombinant LRRK2 protein purchased from Thermo Fisher as an internal control for gel-to-gel relative quantitation of signal. Finally, for pSer1292-LRRK2 relative quantitation, we carried out in vitro autophosphorylation assay of the purchased recombinant LRRK2 protein, as described previously, and loaded the phosphorylated protein as an internal control for all phospho-LRRK2 Western Blot detection experiments.

For the validation experiments, the membranes were incubated with the following primary antibodies: rabbit anti-CD9 (clone D3H4P; Cell Signaling Technology) at 1:5,000 ratio, rabbit antiSTK11 (clone D60C5; Cell Signaling Technology) at 1:1,000 ratio, or mouse anti-PCSK1N (clone NP_037403.1; Millipore-Sigma) at 1:1,000 ratio, or rabbit anti-HNRNPA1 (clone D21H11; Cell Signaling Technology) at 1:1,000 ratio. For the secondary antibody visualization, Goat anti-Rabbit or Goat anti-Mouse Alexa-Fluor $800 \mathrm{~nm}$ (Thermo Fisher Scientific) were used to bind the primary antibodies. An equal amount of pooled urine EVs was loaded in lane 1 of each gel to normalize the signal between two blots. The signal for each sample was then normalized to CD9.

\section{LC-MS Sample Preparation}

Phase-transfer surfactant (PTS) aided procedure was used to lyse the dried EVs and extract proteins $^{74}$. First, EVs were resuspended in the lysis solution containing $12 \mathrm{mM}$ sodium 
medRxiv preprint doi: https://doi.org/10.1101/2022.01.18.22269096; this version posted January 24, 2022. The copyright holder for this preprint (which was not certified by peer review) is the author/funder, who has granted medRxiv a license to display the preprint in perpetuity.

All rights reserved. No reuse allowed without permission.

deoxycholate, $12 \mathrm{mM}$ sodium lauroyl sarcosinate, $10 \mathrm{mM}$ TCEP, $40 \mathrm{mM}$ CAA, and phosphatase inhibitor cocktail (Millipore-Sigma) in $50 \mathrm{mM}$ Tris $\cdot \mathrm{HCl}$, $\mathrm{pH} 8.5$ by incubating $10 \mathrm{~min}$ at $95^{\circ} \mathrm{C}$. During this step, the proteins were also denatured, reduced, and alkylated. The samples were diluted fivefold with $50 \mathrm{mM}$ triethylammonium bicarbonate and digested with Lys-C (Wako) at 1:100 (wt/wt) enzyme-to-protein ratio for $3 \mathrm{~h}$ at $37^{\circ} \mathrm{C}$. For further protein digestion, trypsin was added to a final 1:50 (wt/wt) enzyme-to-protein ratio for overnight digestion at $37^{\circ} \mathrm{C}$. Then, the samples were acidified with trifluoroacetic acid (TFA) to a final concentration of $1 \%$ TFA. An ethyl acetate solution was added at a 1:1 ratio to the samples. The mixture was vortexed for 2 min and then centrifuged at $20,000 \times g$ for 2 min to obtain aqueous and organic phases. The organic phase (top layer) was removed, and the aqueous phase was collected, dried down to $<10 \%$ original volume in a vacuum centrifuge, and desalted using TopTip C18 tips (Glygen) according to the manufacturer's instructions. Each sample was split into $99 \%$ and $1 \%$ aliquots for phosphoproteomic and proteomic experiments, respectively. The samples were dried entirely in a vacuum centrifuge and stored at $-80^{\circ} \mathrm{C}$. For phosphoproteome analysis, the $99 \%$ portion of each sample was subjected to phosphopeptide enrichment using PolyMAC Phosphopeptide Enrichment kit (Tymora Analytical) according to manufacturer's instructions, and the eluted phosphopeptides dried completely in a vacuum centrifuge. The whole enriched sample was loaded onto LC-MS for phosphoproteomics analysis, while only $50 \%$ of each sample was injected for proteomics.

\section{LC-MS Analysis}

Both proteomic and phosphoproteomic samples were spiked with an 11-peptide indexed Retention Time internal standard mixture (Biognosys) to normalize the LC-MS signal between the samples. All samples were captured on a 2-cm Acclaim PepMap trap column and separated on a heated 50cm Acclaim PepMap column (Thermo Fisher Scientific) containing C18 resin. The mobile phase buffer consisted of $0.1 \%$ formic acid in HPLC grade water (buffer $\mathrm{A}$ ) with an eluting buffer containing $0.1 \%$ formic acid in $80 \%(\mathrm{vol} / \mathrm{vol})$ acetonitrile (buffer B) run with a linear 60 -min gradient of $6-30 \%$ 
medRxiv preprint doi: https://doi.org/10.1101/2022.01.18.22269096; this version posted January 24, 2022. The copyright holder for this preprint (which was not certified by peer review) is the author/funder, who has granted medRxiv a license to display the preprint in perpetuity.

All rights reserved. No reuse allowed without permission.

buffer $\mathrm{B}$ at a flow rate of $300 \mathrm{~nL} / \mathrm{min}$. The UHPLC was coupled online with a Q-Exactive HF-X mass spectrometer (Thermo Fisher Scientific). The mass spectrometer was run in the data-dependent mode, in which a full-scan MS (from m/z 375 to 1,500 with the resolution of 60,000 ) was followed by $\mathrm{MS} / \mathrm{MS}$ of the 15 most intense ions $(30,000$ resolution; normalized collision energy - $28 \%$; automatic gain control target (AGC) - 2E4, maximum injection time - $200 \mathrm{~ms}$; 60sec exclusion].

\section{Parallel Reaction Monitoring}

Peptide samples were dissolved in $10.8 \mu \mathrm{L}$ 0.05\% TFA \& $2 \%$ ACN and injected $10 \mu \mathrm{L}$ into the UHPLC coupled with a Q-Exactive HF-X mass spectrometer (Thermo Fisher Scientific). The mobile phase buffer consisted of $0.1 \%$ formic acid in HPLC grade water (buffer A) with an eluting buffer containing $0.1 \%$ formic acid in $80 \%$ (vol/vol) acetonitrile (buffer $\mathrm{B}$ ) run with a linear 60 -min gradient of $5-35 \%$ buffer $B$ at a flow rate of $300 \mathrm{~nL} / \mathrm{min}$. Each sample was analyzed under PRM with an isolation width of $\pm 0.8 \mathrm{Th}$. In these PRM experiments, an MS2 level at 30,000 resolution relative to m/z 200 (AGC target 2E5, 200 ms maximum injection time) was run as triggered by a scheduled inclusion list. Higher-energy collisional dissociation was used with $28 \mathrm{eV}$ normalized collision energy. PRM data were manually curated within Skyline-daily (64-bit) 20.2.1.404 (32d27b598) ${ }^{75}$.

\section{LC-MS Data Processing}

The raw files were searched directly against the human Swiss-Prot database with no redundant entries, using Byonic (Protein Metrics) and Sequest search engines loaded into Proteome Discoverer 2.3 software (Thermo Fisher Scientific). MS1 precursor mass tolerance was set at 10 ppm, and MS2 fragment tolerance was set at $20 \mathrm{ppm}$. In the processing workflow, search criteria for both search engines were performed with full trypsin/P digestion, a maximum of two missed cleavages allowed on the peptides analyzed from the sequence database, a static modification of carbamidomethylation on cysteines $(+57.0214 \mathrm{Da})$, and variable modifications of oxidation (+15.9949 Da) on methionine residues and acetylation $(+42.011 \mathrm{Da})$ at $\mathrm{N}$ terminus of proteins. Phosphorylation (+79.996 Da) on serine, threonine, or tyrosine residues was included as the variable modification for phosphoproteome analysis. The false-discovery rates of proteins and 
medRxiv preprint doi: https://doi.org/10.1101/2022.01.18.22269096; this version posted January 24, 2022. The copyright holder for this preprint (which was not certified by peer review) is the author/funder, who has granted medRxiv a license to display the preprint in perpetuity.

All rights reserved. No reuse allowed without permission.

peptides were set at 0.01 . All protein and peptide identifications were grouped, and any redundant entries were removed. Unique peptides and unique master proteins were reported. Finally, the proteomic results were further normalized against common urine EV proteins to account for any other variations in urine concentration.

\section{Label-free Quantitation Analysis}

The label-free quantitation node of Precursor lons Quantifier in the consensus workflow through the Proteome Discoverer v2.3 (Thermo Fisher Scientific) was used to quantify all data. For the quantification of proteomic and phosphoproteomic data, the intensities of peptides were extracted with initial precursor mass tolerance set at $10 \mathrm{ppm}$, fragment mass tolerance at $0.02 \mathrm{Da}$, minimum peak count as 1, maximum RT shift as $5 \mathrm{~min}$, PSM confidence FDR of 0.01 as strict and 0.05 as relaxed, with hypothesis test of t-test (background based), maximum RT shift of 5 min, protein abundance based ratio calculation, 100 as the maximum allowed fold change, and site probability threshold of 75 . The abundance levels of all peptides and proteins were normalized to the spikedin internal iRT standard. For calculations of protein abundance, the sum of sample abundances of the connected peptide groups was added together and used for downstream analysis.

\section{Bioinformatics Analysis}

All clinical sample data were analyzed using the Perseus software (version 1.6.1.5) ${ }^{76}$. The normalized intensities of proteins and phosphoproteins were extracted from Proteome Discoverer search results and log-based 2 transformed for quantifying both proteomic and phosphoproteomic data. The abundances were categorized into four different categories: Control, NMC, iPD, and LRRK2 PD. The proteins or phosphoproteins with detected abundances of more than $70 \%$ in each category were kept. It was done to keep the proteins and phosphoproteins detected in at least one category. The imputation for the missing abundances was performed by assigning small random values from the normal distribution with a downshift of 1.8 SDs and a width of 0.3 SDs. Very low abundances normally cause missing values. 
medRxiv preprint doi: https://doi.org/10.1101/2022.01.18.22269096; this version posted January 24, 2022. The copyright holder for this preprint (which was not certified by peer review) is the author/funder, who has granted medRxiv a license to display the preprint in perpetuity.

All rights reserved. No reuse allowed without permission.

All abundances for each protein or phosphoproteins were further normalized by subtracting the median from each protein or phosphoprotein abundance. Then, the unpaired two-tail student t-test was performed, and the difference in averages was calculated for the three comparisons. Various packages in R 3.5.0 $0^{77}$, including but not limited to ggplot2 3.3.1 ${ }^{78}$, ggpubr $0.3 .0^{79}$, EnhancedVolcano 1.7.6 $6^{80}, \mathrm{pROC}^{81}$, Vennerable $3.0^{82}$, and Circlize $0.4 .9^{83}$, and also Cytoscape $3.8 .0^{84}$ (an open-source software platform for visualizing complex networks) were used to visualize the data. For the volcano plots, the $x$-axis is the $\log (2)$ difference on averages, and the $y$-axis is the $\log (10)$ of the $p$-value. Volcano plots were created for each of comparison with cut-off values of $p$-value $=0.05(-$ $\log 10(0.05)=1.30)$ and log base 2 difference $=0.5$, which equals to $\sim 1.414$ fold-change. The Venn diagrams were created based on the upregulated proteins or phosphoproteins in the volcano plots. The violin plots were generated by focusing on significant proteins and phosphoproteins from the overlapped area in the Venn diagrams, which represented 2 different categories: disease markers and risk markers. The two-tail t-test p-values and the one-way ANOVA p-value were included on each of the violin plots. The correlations between potential biomarker expressions with gender, age, disease duration, and MoCA were created with a minimal 0.6 for $R^{2}$ and a maximal 0.05 for $p$-value as thresholds. Gene ontology analysis was performed using Gene Ontology enRIchment anaLysis and visualizAtion tool (GOrilla) ${ }^{47}$. Lastly, STRING $v 11^{85}$ and IPA ${ }^{86}$ (QIAGEN Inc., https://www.qiagenbioinformatics.com/products/ingenuitypathway-analysis) were used to analyze the protein-protein interactions and validate their respective protein roles in hallmark PD pathways.

\section{Division Into Training Set and Test Set, Feature Selection, and Predictive Analysis}

One hundred forty-one unique subjects were divided randomly into the discovery and validation experiments. In total, 82 subjects were categorized into the main experiment, further divided into training (57 subjects) and test sets (25 subjects). Fifty-nine subjects were used for the validation experiments, consisting of parallel reaction monitoring and Western Blot experiments. For the discovery experiment, we first performed feature selection on the biomarker candidates obtained from Supplementary Figure 9. Instead of using a simple one-shot feature selection technique 
medRxiv preprint doi: https://doi.org/10.1101/2022.01.18.22269096; this version posted January 24, 2022. The copyright holder for this preprint (which was not certified by peer review) is the author/funder, who has granted medRxiv a license to display the preprint in perpetuity.

All rights reserved. No reuse allowed without permission.

that usually yields a sub-optimal solution, we used a two-step feature selection process that generates better performance: backward feature elimination followed by exhaustive feature selection $^{68}$. We deployed backward feature elimination which removes, one feature at a time, those features that did not have a significant effect on the dependent variable or prediction of output. Then, we deployed exhaustive feature selection, which aims at finding the best performing feature subset by searching across all possible feature combinations (a brute-force method) until the desired number of features is left. Specifically, this number was determined by observing the increase in performance (accuracy) with the increase in the number of final selected features (in which it is diminishing return).

Next, we performed a hyperparameters selection process which included a randomized search followed by an exhaustive search on a random forest classifier. In particular, we searched over the following set of hyperparameters: 'n_estimators,' 'max_features,' 'max_depth,' 'min_samples_split,' 'min_samples_leaf,' and 'bootstrap' in which we validated the result by using ten-fold cross-validation. In randomized search, we searched across 200 different combinations of hyperparameters and then created the hyperparameter grid encompassing the optimal sampled hyperparameter combination from the randomized search. An exhaustive search was used to select the best performing set of hyperparameters from the generated grid. Finally, we tested our constructed model (with carefully chosen features and hyperparameters described above) 50 times and evaluated it by considering the accuracy, confusion matrix, and ROC curve. Finally, we repeatedly trained a Random Forest Classifier with the selected features and hyperparameters obtained from the above processes 50 times. After that, we evaluated each constructed model using accuracy, confusion matrix, and ROC curve. To summarize the results over all trials, we computed each evaluation metric's mean and 95\% confidence interval.

\section{Acknowledgements}


medRxiv preprint doi: https://doi.org/10.1101/2022.01.18.22269096; this version posted January 24, 2022. The copyright holder for this preprint (which was not certified by peer review) is the author/funder, who has granted medRxiv a license to display the preprint in perpetuity.

All rights reserved. No reuse allowed without permission.

This project was partially supported by The Michael J. Fox Foundation for Parkinson's Research (Grant ID 17453) and NIH grant (Grant ID 3RF1AG064250). We also thank Dr. Andrew West and Shijie Wang for their protocol suggestions for LRRK2 autophosphorylation and p-LRRK2 detection on Western Blot. Cartoon in Figure 1 created with BioRender.com.

\section{Contributions}

A.I. and L.L. performed the experiments and analyzed the data. M.H. carried out the bioinformatics and statistical analyses, and generated the figures, final data, and markers. M.H. and K.K. designed, optimized, and executed the machine learning. X.W. conducted the urine normalization and optimized the PRM method. M.H. and Z.L. designed and created Figure 1 with BioRender.com. R.N.A. provided the urine samples and information about the cohort. A.I., S.P, and W.A.T. conceived the project and designed the experiments. M.H., A.I., and W.A.T. wrote the paper. All authors reviewed and approved the manuscript.

\section{Competing Interests}

The authors declare a competing financial interest. A.I. and W.A.T. are principals at Tymora Analytical Operations, which developed EVtrap beads and commercialized PolyMAC enrichment kit. 
medRxiv preprint doi: https://doi.org/10.1101/2022.01.18.22269096; this version posted January 24, 2022. The copyright holder for this preprint (which was not certified by peer review) is the author/funder, who has granted medRxiv a license to display the preprint in perpetuity.

\section{References}

1. Zeng, X. S., Geng, W. S., Jia, J. J., Chen, L. \& Zhang, P. P. Cellular and molecular basis of neurodegeneration in Parkinson disease. Front. Aging Neurosci. 10, 1-16 (2018).

2. Rui, Q., Ni, H., Li, D., Gao, R. \& Chen, G. The Role of LRRK2 in Neurodegeneration of Parkinson Disease. Curr. Neuropharmacol. 16, 1348-1357 (2018).

3. Houlden, H. \& Singleton, A. B. The genetics and neuropathology of Parkinson's disease. Acta Neuropathol. 124, 325-338 (2012).

4. Adams, B. et al. Parkinson's disease: A systemic inflammatory disease accompanied by bacterial inflammagens. Front. Aging Neurosci. 10, 1-17 (2019).

5. Tibar, H. et al. Non-motor symptoms of Parkinson's Disease and their impact on quality of life in a cohort of Moroccan patients. Front. Neurol. 9, 1-12 (2018).

6. Zhong, J. et al. Integrated profiling of single cell epigenomic and transcriptomic landscape of Parkinson's disease mouse brain. bioRvix (2020) doi:10.1101/2020.02.04.933259.

7. Reeve, A., Simcox, E. \& Turnbull, D. Ageing and Parkinson's disease: Why is advancing age the biggest risk factor? Ageing Res. Rev. 14, 19-30 (2014).

8. Hughes, R. C. Parkinson's Disease and its Management. Bmj 308, 281 (1994).

9. Marras, C. et al. Prevalence of Parkinson's disease across North America. npj Park. Dis. 4, 1-7 (2018).

10. Burbulla, L. F. \& Krüger, R. Converging environmental and genetic pathways in the pathogenesis of Parkinson's disease. J. Neurol. Sci. 306, 1-8 (2011).

11. Chang, D. et al. A meta-analysis of genome-wide association studies identifies 17 new Parkinson's disease risk loci. Nat. Genet. 49, 1511-1516 (2017).

12. Satake, W. et al. Genome-wide association study identifies common variants at four loci as genetic risk factors for Parkinson's disease. Nat. Genet. 41, 1303-1307 (2009).

13. Simón-Sánchez, J. et al. Genome-wide association study reveals genetic risk underlying Parkinson's disease. Nat. Genet. 41, 1308-1312 (2009). 
14. Price, A., Manzoni, C., Cookson, M. R. \& Lewis, P. A. The LRRK2 signalling system. Cell Tissue Res. 373, 39-50 (2018).

15. Marín, I., Egmond, W. N. \& Haastert, P. J. M. The Roco protein family: a functional perspective. FASEB J. 22, 3103-3110 (2008).

16. Alessi, D. R. \& Sammler, E. LRRK2 kinase in Parkinson's disease. Science (80-. ). 360, 36-37 (2018).

17. Migheli, R. et al. LRRK2 Affects Vesicle Trafficking, Neurotransmitter Extracellular Level and Membrane Receptor Localization. PLoS One 8, e77198 (2013).

18. Margolis, L. \& Sadovsky, Y. The biology of extracellular vesicles: The known unknowns. PLOS Biol. 17, 1-12 (2019).

19. Zhang, Y., Wu, X. \& Tao, W. A. Characterization and applications of extracellular vesicle proteome with post-translational modifications. TrAC - Trends Anal. Chem. 107, 21-30 (2018).

20. Santucci, L. et al. Biological surface properties in extracellular vesicles and their effect on cargo proteins. Sci. Rep. 9, 1-12 (2019).

21. Yang, K. S. et al. Multiparametric plasma EV profiling facilitates diagnosis of pancreatic malignancy. Sci. Transl. Med. 9, eaal3226 (2017).

22. Verma, M., Lam, T. K., Hebert, E. \& Divi, R. L. Extracellular vesicles: Potential applications in cancer diagnosis, prognosis, and epidemiology. BMC Clin. Pathol. 15, 1-9 (2015).

23. Xu, R., Greening, D. W., Zhu, H.-J., Takahashi, N. \& Simpson, R. J. Extracellular vesicle isolation and characterization: toward clinical application. J. Clin. Invest. 126, 1152-1162 (2016).

24. Lin, J. et al. Exosomes: Novel Biomarkers for Clinical Diagnosis. Sci. World J. 2015, (2015).

25. Chen, I. H. et al. Phosphoproteins in extracellular vesicles as candidate markers for 
medRxiv preprint doi: https://doi.org/10.1101/2022.01.18.22269096; this version posted January 24, 2022. The copyright holder for this preprint (which was not certified by peer review) is the author/funder, who has granted medRxiv a license to display the preprint in perpetuity.

All rights reserved. No reuse allowed without permission.

breast cancer. Proc. Natl. Acad. Sci. U. S. A. 114, 3175-3180 (2017).

26. Iliuk, A. et al. Plasma-Derived Extracellular Vesicle Phosphoproteomics through Chemical Affinity Purification. J. Proteome Res. (2020) doi:10.1021/acs.jproteome.0c00151.

27. Alcalay, R. N. et al. Higher Urine bis(Monoacylglycerol)Phosphate Levels in LRRK2 G2019S Mutation Carriers: Implications for Therapeutic Development. Mov. Disord. 35, 134-141 (2020).

28. Buljan, M., Blattmann, P., Aebersold, R. \& Boutros, M. Systematic characterization of pan-cancer mutation clusters. Mol. Syst. Biol. 14, 1-19 (2018).

29. Le Large, T. Y. S. et al. Key biological processes driving metastatic spread of pancreatic cancer as identified by multi-omics studies. Semin. Cancer Biol. 44, 153-169 (2017).

30. Pishvaian, M. J. et al. Molecular profiling of patients with pancreatic cancer: Initial results from the know your tumor initiative. Clin. Cancer Res. 24, 5018-5027 (2018).

31. Chen, F., Chandrashekar, D. S., Varambally, S. \& Creighton, C. J. Pan-cancer molecular subtypes revealed by mass-spectrometry-based proteomic characterization of more than 500 human cancers. Nat. Commun. 10, 1-15 (2019).

32. Chen, F. et al. Multiplatform-based molecular subtypes of non-small-cell lung cancer. Oncogene 36, 1384-1393 (2017).

33. Li, J. et al. Characterization of Human Cancer Cell Lines by Reverse-phase Protein Arrays. Cancer Cell 31, 225-239 (2017).

34. Mundt, F. et al. Mass spectrometry-based proteomics reveals potential roles of NEK9 and MAP2K4 in resistance to PI3K inhibition in triple-negative breast cancers. Cancer Res. 78, 2732-2746 (2018).

35. Wulfkuhle, J. D. et al. Molecular analysis of HER2 signaling in human breast cancer by functional protein pathway activation mapping. Clin. Cancer Res. 18, 6426-6435 (2012).

36. Wulfkuhle, J. D. et al. Evaluation of the HER/PI3K/AKT Family Signaling Network as a Predictive Biomarker of Pathologic Complete Response for Patients With Breast Cancer 
medRxiv preprint doi: https://doi.org/10.1101/2022.01.18.22269096; this version posted January 24, 2022. The copyright holder for this preprint (which was not certified by peer review) is the author/funder, who has granted medRxiv a license to display the preprint in perpetuity.

All rights reserved. No reuse allowed without permission.

Treated With Neratinib in the I-SPY 2 TRIAL. JCO Precis. Oncol. 1-20 (2018) doi:10.1200/po.18.00024.

37. Zagorac, I. et al. In vivo phosphoproteomics reveals kinase activity profiles that predict treatment outcome in triple-negative breast cancer. Nat. Commun. 9, (2018).

38. Huang, K. L. et al. Proteogenomic integration reveals therapeutic targets in breast cancer xenografts. Nat. Commun. 8, (2017).

39. Wang, S. et al. Elevated LRRK2 autophosphorylation in brain-derived and peripheral exosomes in LRRK2 mutation carriers. Acta Neuropathol. Commun. 5, 86 (2017).

40. Fraser, K. B., Moehle, M. S., Alcalay, R. N. \& West, A. B. Urinary LRRK2 phosphorylation predicts parkinsonian phenotypes in G2019S LRRK2 carriers. Neurology 86, 994-999 (2016).

41. Fraser, K. B. et al. Ser(P)-1292 LRRK2 in urinary exosomes is elevated in idiopathic Parkinson's disease. Mov. Disord. 31, 1543-1550 (2016).

42. Virreira Winter, S. et al. Urinary proteome profiling for stratifying patients with familial Parkinson's disease. EMBO Mol. Med. 2020.08.09.243584 (2021) doi:10.15252/emmm.202013257.

43. Alcalay, R. N. et al. Parkinson disease phenotype in Ashkenazi jews with and without LRRK2 G2019S mutations. Mov. Disord. 28, 1966-1971 (2013).

44. Wu, X., Li, L., Iliuk, A. \& Tao, W. A. Highly Efficient Phosphoproteome Capture and Analysis from Urinary Extracellular Vesicles. J. Proteome Res. 17, 3308-3316 (2018).

45. Uhlen, M. et al. Tissue-based map of the human proteome. Science (80-. ). 347, $1260419-1260419$ (2015).

46. Zhu, Q. et al. The genetic source tracking of human urinary exosomes. Proc. Natl. Acad. Sci. U. S. A. 118, 10-12 (2021).

47. Eden, E., Navon, R., Steinfeld, I., Lipson, D. \& Yakhini, Z. GOrilla: A tool for discovery and visualization of enriched GO terms in ranked gene lists. BMC Bioinformatics 10, 1-7 
(2009).

48. Videira, P. A. Q. \& Castro-Caldas, M. Linking glycation and glycosylation with inflammation and mitochondrial dysfunction in Parkinson's disease. Front. Neurosci. 12, $1-20(2018)$.

49. Trezzi, J. P. et al. Distinct metabolomic signature in cerebrospinal fluid in early parkinson's disease. Mov. Disord. 32, 1401-1408 (2017).

50. Niewiarowska-Sendo, A., Kozik, A. \& Guevara-Lora, I. Kinin Peptides Enhance Inflammatory and Oxidative Responses Promoting Apoptosis in a Parkinson's Disease Cellular Model. Mediators Inflamm. 2016, (2016).

51. Everse, J., Liu, C. J. J. \& Coates, P. W. Physical and catalytic properties of a peroxidase derived from cytochrome c. Biochim. Biophys. Acta - Mol. Basis Dis. 1812, 1138-1145 (2011).

52. Sato, Y., Kaji, M., Metoki, N., Yoshida, H. \& Satoh, K. Coagulation-fibrinolysis abnormalities in patients receiving antiparkinsonian agents. J. Neurol. Sci. 212, 55-58 (2003).

53. Lev, N., Melamed, E. \& Offen, D. Apoptosis and Parkinson's disease. Prog. NeuroPsychopharmacology Biol. Psychiatry 27, 245-250 (2003).

54. Araki, K. et al. Parkinson's disease is a type of amyloidosis featuring accumulation of amyloid fibrils of a-synuclein. Proc. Natl. Acad. Sci. U. S. A. 116, 17963-17969 (2019).

55. Fouillet, A. et al. ER stress inhibits neuronal death by promoting autophagy. Autophagy 8 , 915-926 (2012).

56. Cerri, S., Mus, L. \& Blandini, F. Parkinson's Disease in Women and Men: What's the Difference? J. Parkinsons. Dis. 9, 501-515 (2019).

57. Baldereschi, M. et al. Parkinson's disease and parkinsonism in a longitudinal study: Twofold higher incidence in men. Neurology 55, 1358-1363 (2000).

58. Vásquez, K. A., Valverde, E. M., Aguilar, D. V. \& Gabarain, H. J. H. Montreal cognitive 
assessment scale in patients with parkinson disease with normal scores in the minimental state examination. Dement. e Neuropsychol. 13, 78-81 (2019).

59. Sun, Y., Vashisht, A. A., Tchieu, J., Wohlschlegel, J. A. \& Dreier, L. Voltage-dependent anion channels (VDACs) recruit parkin to defective mitochondria to promote mitochondrial autophagy. J. Biol. Chem. 287, 40652-40660 (2012).

60. Klein, A. D. \& Mazzulli, J. R. Is Parkinson's disease a lysosomal disorder? Brain 141, 2255-2262 (2018).

61. Sarkar, C. et al. PLA2G4A/cPLA2-mediated lysosomal membrane damage leads to inhibition of autophagy and neurodegeneration after brain trauma. Autophagy 16, 466485 (2019).

62. Mudannayake, J. M., Mouravlev, A., Fong, D. M. \& Young, D. Transcriptional activity of novel ALDH1L1 promoters in the rat brain following AAV vector-mediated gene transfer. Mol. Ther. - Methods Clin. Dev. 3, 16075 (2016).

63. Romano, R. \& Bucci, C. Role of EGFR in the Nervous System. Cells 9, (2020).

64. Cassani, E. et al. Cardiometabolic factors and disease duration in patients with Parkinson's disease. Nutrition 29, 1331-1335 (2013).

65. Klemann, C. J. H. M. et al. Integrated molecular landscape of Parkinson's disease. npj Park. Dis. 3, (2017).

66. He, R. et al. Recent advances in biomarkers for Parkinson's disease. Front. Aging Neurosci. 10, 1-19 (2018).

67. Carecchio, M. \& Comi, C. The role of osteopontin in neurodegenerative diseases. J. Alzheimer's Dis. 25, 179-185 (2011).

68. Trevor Hastie, Robert Tibshirani, J. F. The Elements of Statistical Learning: Data Mining, Inference, and Prediction. in 57-60 (Springer, 2009).

69. Di Maio, R. et al. LRRK2 activation in idiopathic Parkinson's disease. Sci. Transl. Med. 10, 1-13 (2018). 
70. Petridi, S. et al. Neurodegeneration caused by LRRK2-G2019S requires Rab10 in select dopaminergic neurons. bioRxiv 586073 (2019) doi:10.1101/586073.

71. Seol, W., Nam, D. \& Son, I. Rab GTPases as physiological substrates of LRRK2 kinase. Exp. Neurobiol. 28, 134-145 (2019).

72. Cova, I. \& Priori, A. Diagnostic biomarkers for Parkinson's disease at a glance: where are we? J. Neural Transm. 125, 1417-1432 (2018).

73. Oberg, A. L. \& Vitek, O. Statistical design of quantitative mass spectrometry-based proteomic experiments. J. Proteome Res. 8, 2144-2156 (2009).

74. Zeringer, E. Methods for the extraction and RNA profiling of exosomes. World J. Methodol. 3, 11 (2013).

75. MacLean, B. et al. Skyline: An open source document editor for creating and analyzing targeted proteomics experiments. Bioinformatics 26, 966-968 (2010).

76. Tyanova, S. et al. The Perseus computational platform for comprehensive analysis of (prote)omics data. Nat. Methods 13, 731-740 (2016).

77. R Core Team. R: A Language and Environment for Statistical Computing. (2013).

78. Hadley Wickham. ggplot2: Elegant Graphics for Data Analysis. (Springer-Verlag New York, 2016).

79. Kassambara, A. ggpubr: 'ggplot2' Based Publication Ready Plots. (2020).

80. Blighe, K. EnhancedVolcano: Publication-ready volcano plots with enhanced colouring and labeling. (2018).

81. Robin, X. et al. pROC: an open-source package for R and $\mathrm{S}+$ to analyze and compare ROC curves. BMC Bioinformatics 12, 77 (2011).

82. Jonathan Swinton. Vennerable: Venn and Euler area-proportional diagrams. (2019).

83. Zuguang Gu, Lei Gu, Roland Eils, Matthias Schlesner, B. B. circlize implements and enhances circular visualization in R. Bioinformatics 30, 2811-2812 (2014).

84. Shannon, P. Cytoscape: A Software Environment for Integrated Models of Biomolecular 
medRxiv preprint doi: https://doi.org/10.1101/2022.01.18.22269096; this version posted January 24, 2022. The copyright holder for this preprint

(which was not certified by peer review) is the author/funder, who has granted medRxiv a license to display the preprint in perpetuity.

All rights reserved. No reuse allowed without permission.

Interaction Networks. Genome Res. 13, 2498-2504 (2003).

85. Szklarczyk, D. et al. STRING v11: Protein-protein association networks with increased

coverage, supporting functional discovery in genome-wide experimental datasets. Nucleic

Acids Res. 47, D607-D613 (2019).

86. Krämer, A., Green, J., Pollard, J. \& Tugendreich, S. Causal analysis approaches in ingenuity pathway analysis. Bioinformatics 30, 523-530 (2014). 


\section{Supplementary Figure 1}
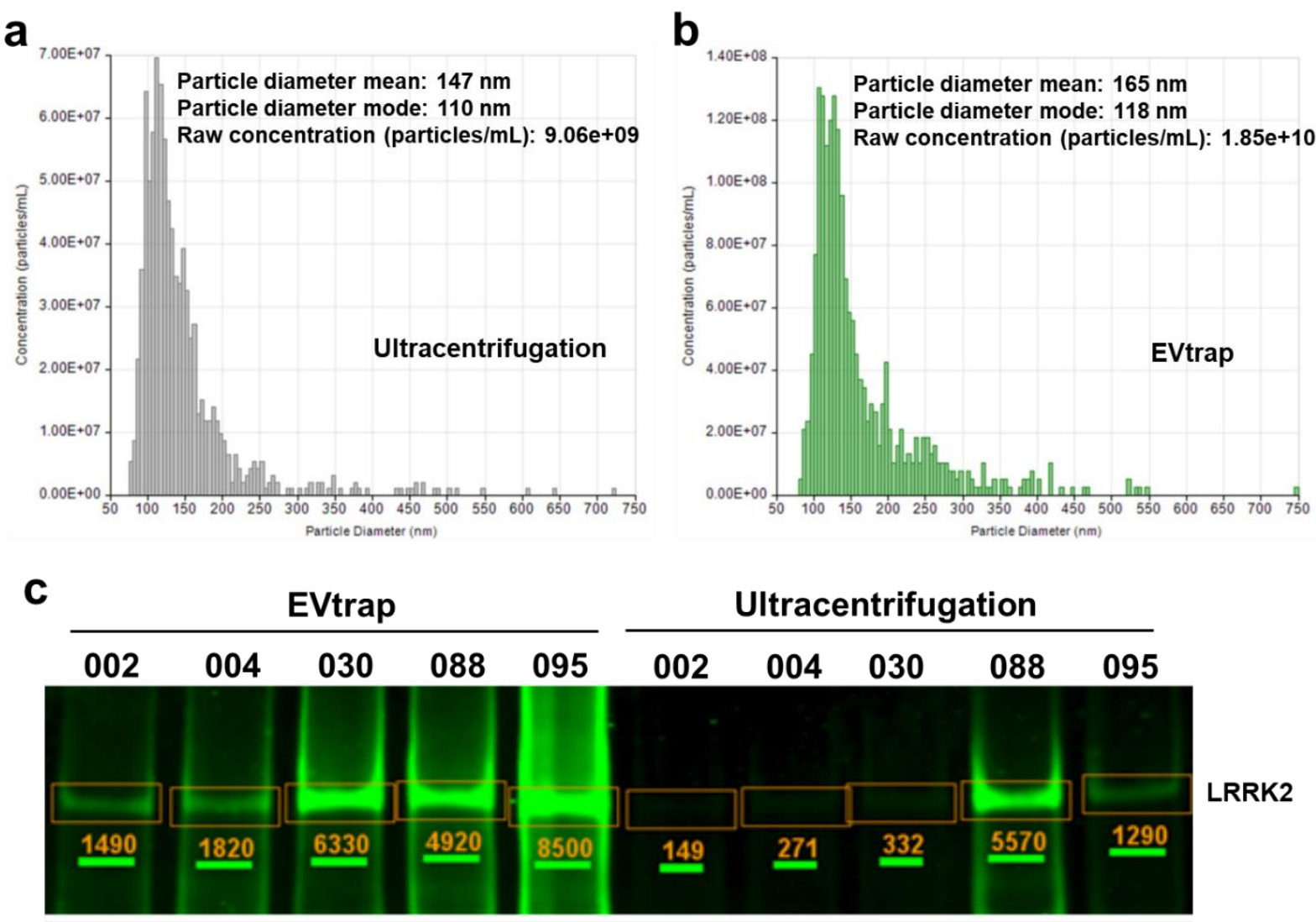

Ultracentrifugation

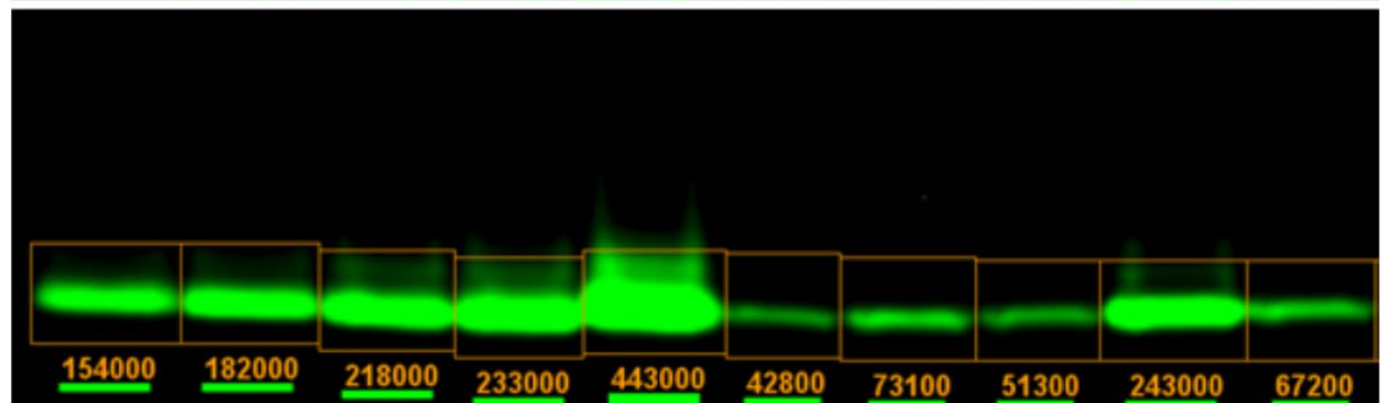

Supplementary Figure 1. Comparison of EVtrap and ultracentrifugation for EV capture from urine. TRPS analysis of EVs captured by a) ultracentrifugation or b) EVtrap. c) Western blot detection of CD9 and LRRK2 proteins of 5 urine EV samples isolated by EVtrap or ultracentrifugation. 


\section{Supplementary Figure 2}

a
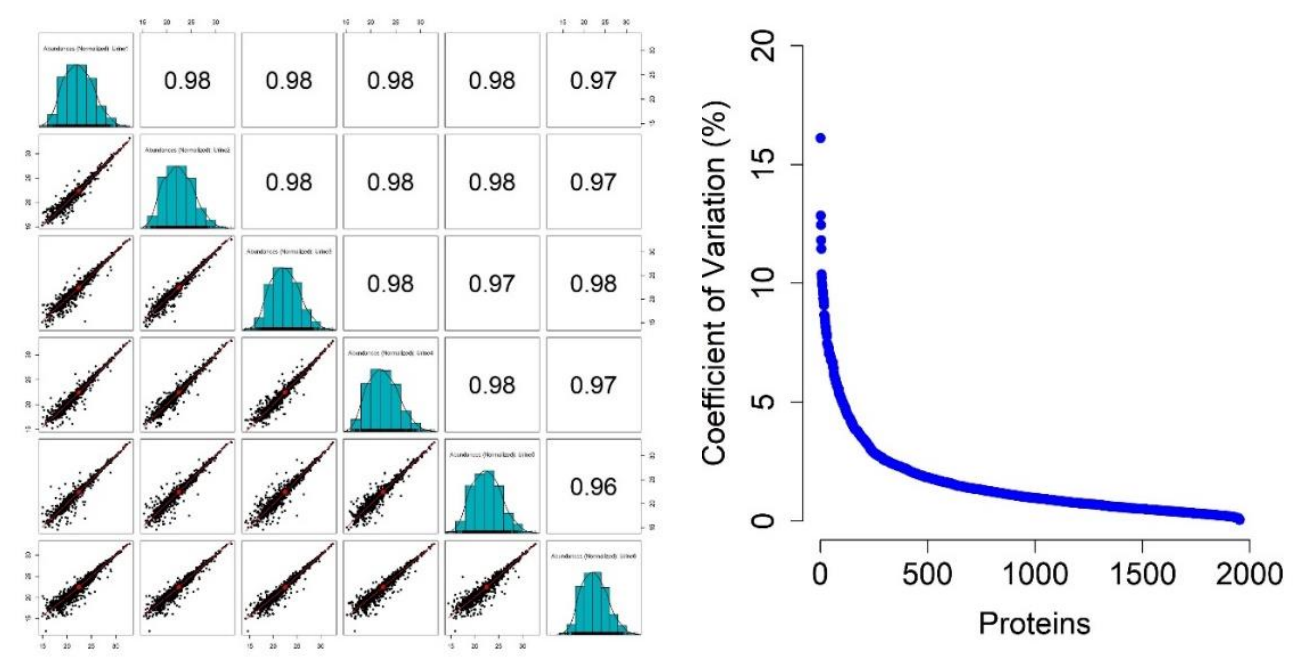

b

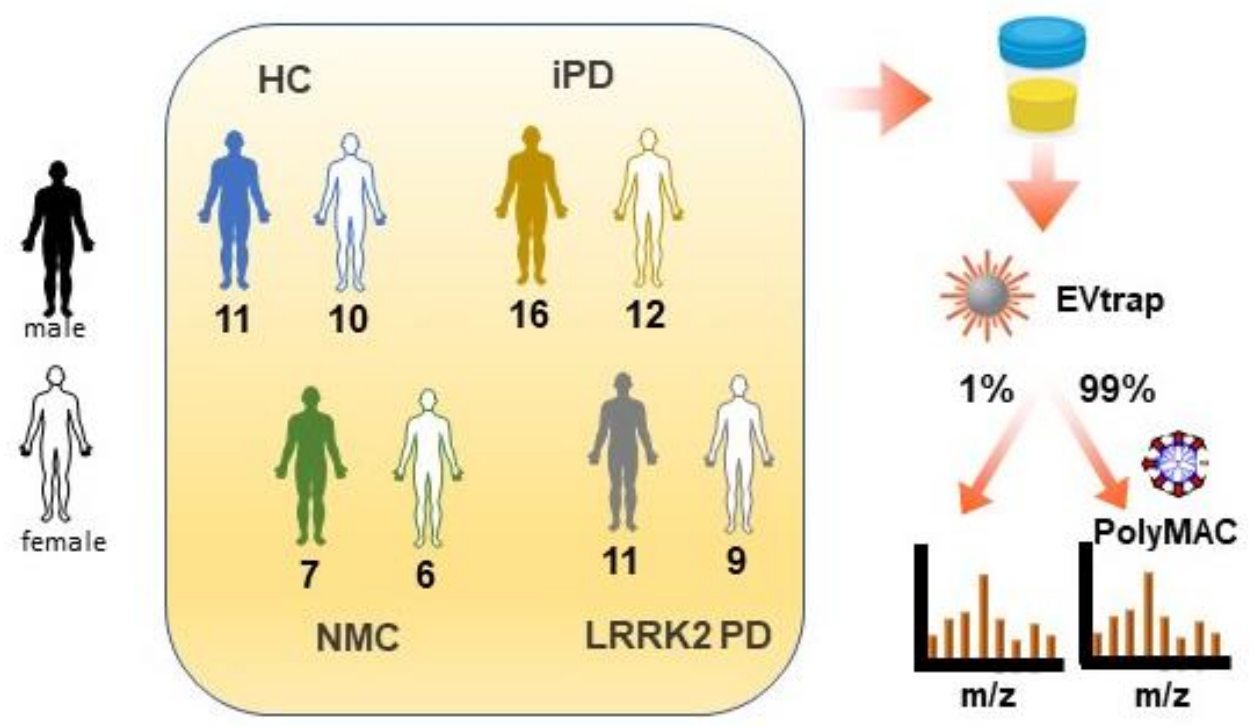

Supplementary Figure 2. The reproducibility evaluation of our complete urine EV analysis protocol and the analytical sample preparation workflow. To evaluate the procedural reproducibility, a single urine sample was separated into six aliquots and processed with our EVtrap-LCMS protocol as six technical replicates. a) We created a multi-scatter plot accompanied by Pearson correlation coefficients and a distribution plot of proteins by a coefficient of variation (\%). b) Workflow for urine samples processing. 


\section{Supplementary Figure 3}

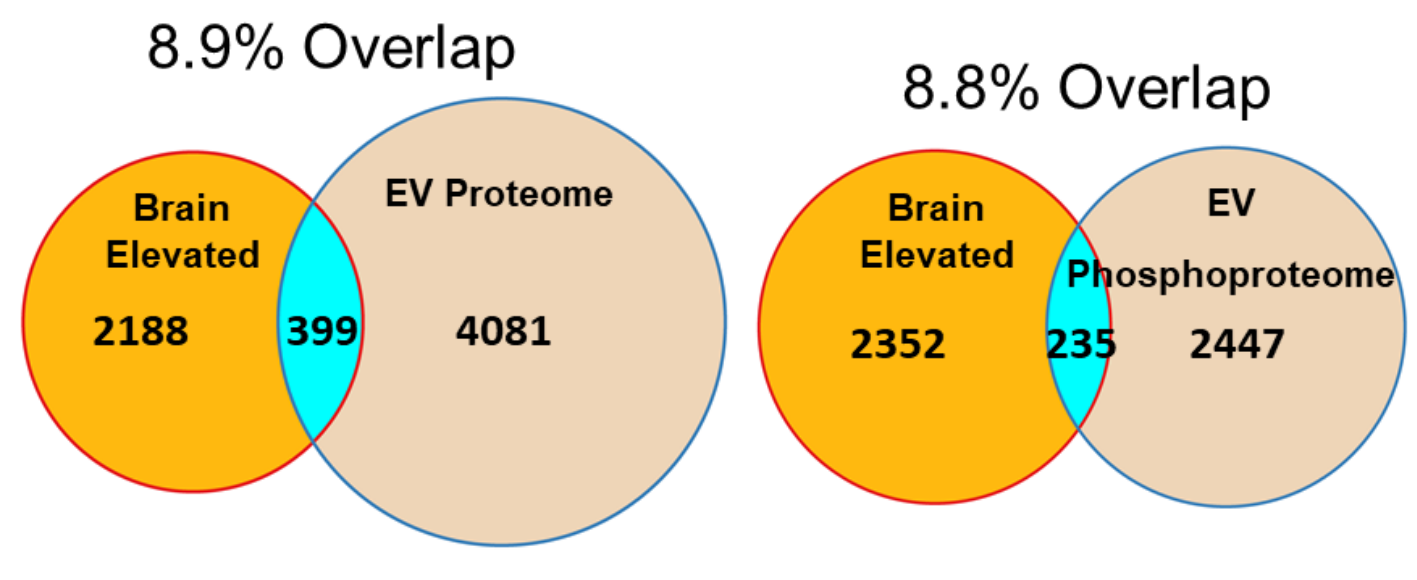

Supplementary Figure 3. The overlap of our identified proteomic and phosphoproteomic data with available brain-elevated RNA-seq data downloaded from the Human Protein Atlas website. We used 2587 proteins classified as brain-elevated from the Human Protein Atlas for comparison with our identified EV proteins and phosphoproteins. 
medRxiv preprint doi: https://doi.org/10.1101/2022.01.18.22269096; this version posted January 24, 2022. The copyright holder for this preprint (which was not certified by peer review) is the author/funder, who has granted medRxiv a license to display the preprint in perpetuity.

All rights reserved. No reuse allowed without permission.

\section{Supplementary Figure 4}

a

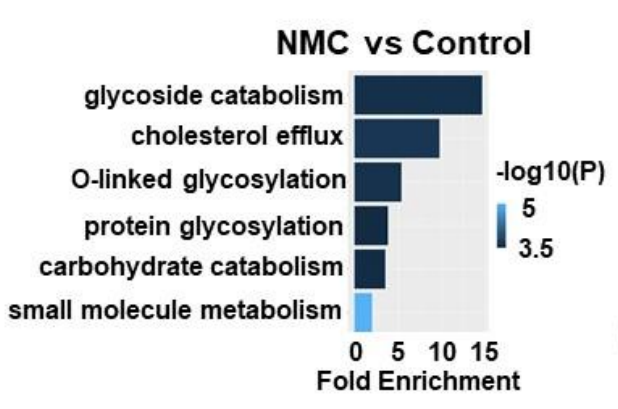

C

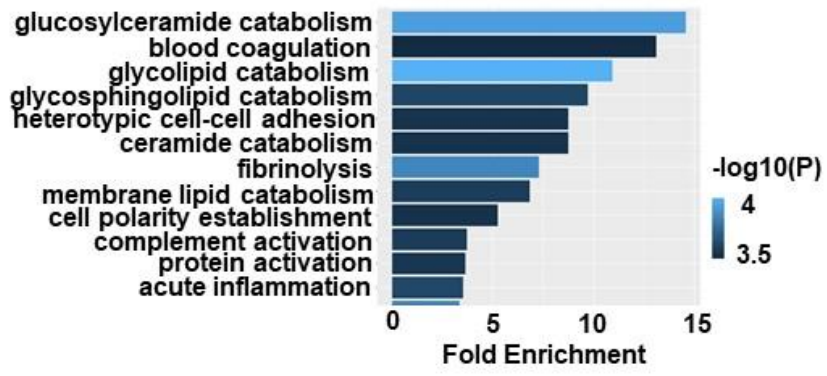

b

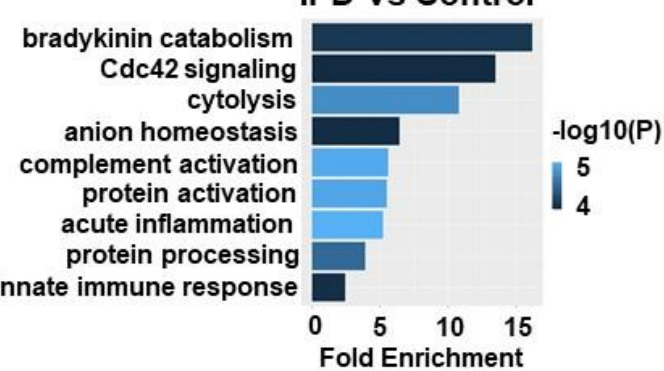

d

LRRK2 PD vs NMC

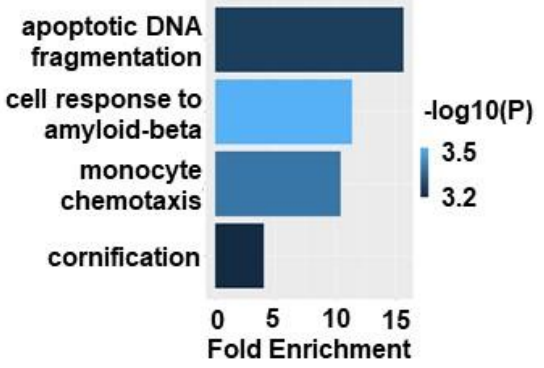

\section{Supplementary Figure 4. Enriched biological process gene ontology analyses of up-} regulated proteins. GO analyses for a) NMC compared to control; b) iPD compared to control; c) LRRK2 PD compared to control; d) LRRK2 PD compared to NMC samples. The analyses were carried out with the GOrilla. 


\section{Supplementary Figure 5}
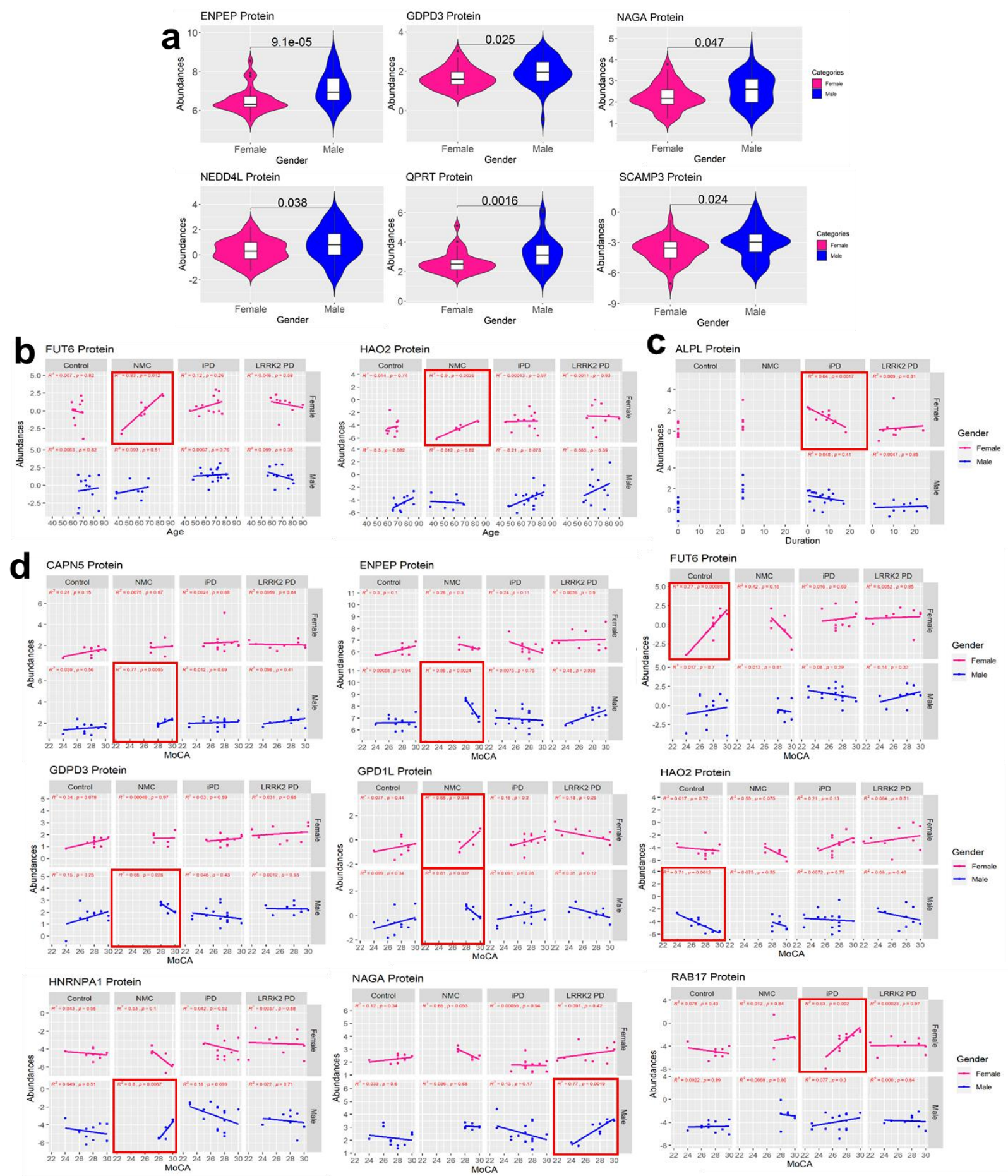

Supplementary Figure 5. Correlation analysis for select potential protein biomarkers from the full data set (training and test sets). a) ENPEP, GDPD3, NAGA, NEDD4L, QPRT, and SCAMP3 proteins were expressed higher in males. b) The correlation analysis between FUT6 and $\mathrm{HAO} 2$ protein abundances and age for each group according to gender. c) The correlation analysis between ALPL protein abundances and disease duration for each group according to gender. d) The correlation analysis between CAPN5, ENPEP, FUT6, GDPD3, GPD1L, HAO2, 
medRxiv preprint doi: https://doi.org/10.1101/2022.01.18.22269096; this version posted January 24, 2022. The copyright holder for this preprint (which was not certified by peer review) is the author/funder, who has granted medRxiv a license to display the preprint in perpetuity.

All rights reserved. No reuse allowed without permission.

HNRNPA1, NAGA, and RAB17 protein abundances and MoCA for each group according to the gender. The red-bordered areas show either positive or negative correlations. 
medRxiv preprint doi: https://doi.org/10.1101/2022.01.18.22269096; this version posted January 24, 2022. The copyright holder for this preprint (which was not certified by peer review) is the author/funder, who has granted medRxiv a license to display the preprint in perpetuity. All rights reserved. No reuse allowed without permission.

\section{Supplementary Figure 6}
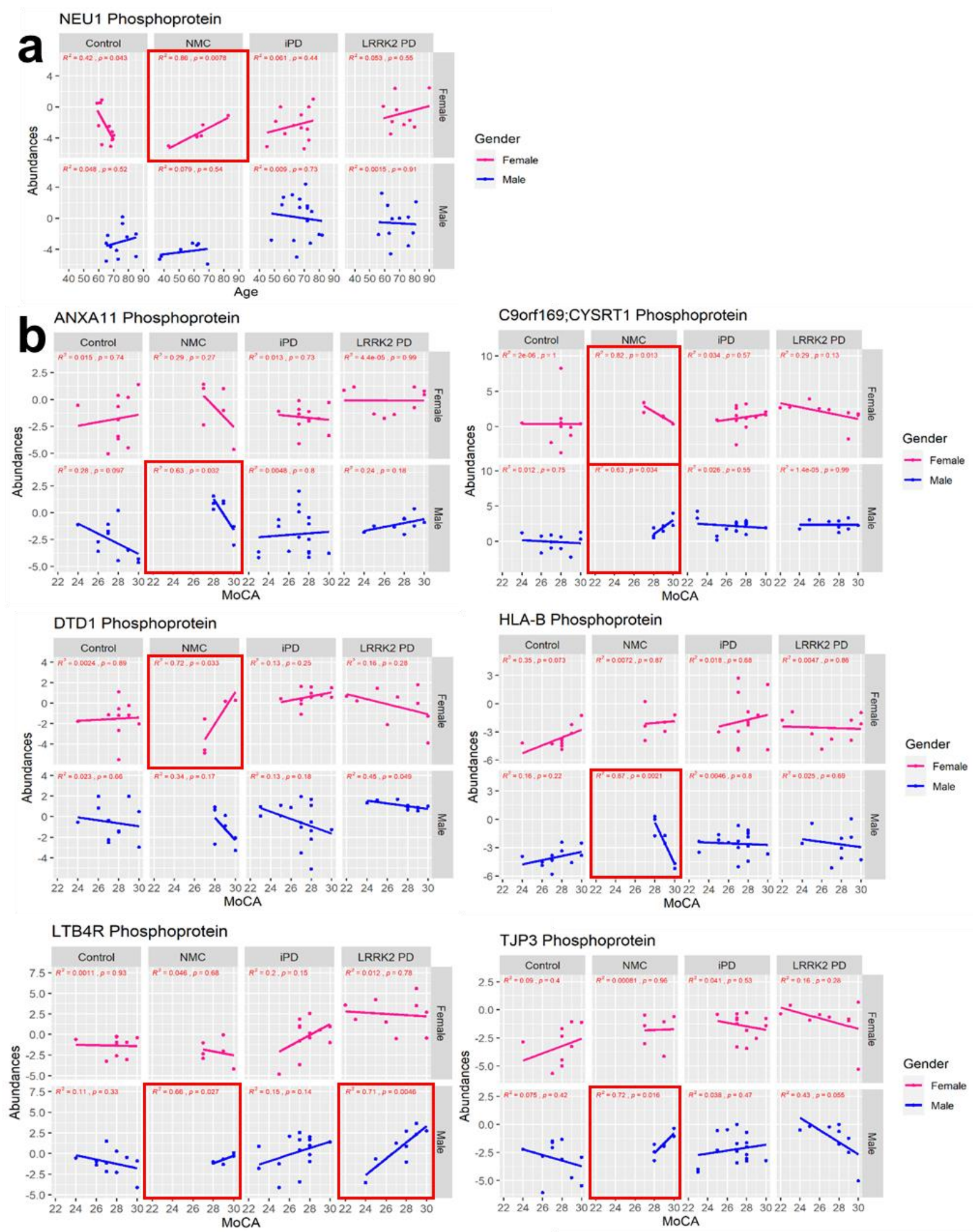

Supplementary Figure 6. Correlation analysis for select potential phosphoprotein biomarkers from the full data set (training and test sets). a) The correlation analysis between NEU1 phosphoprotein abundances and age for each group according to gender. b) The 
medRxiv preprint doi: https://doi.org/10.1101/2022.01.18.22269096; this version posted January 24, 2022. The copyright holder for this preprint (which was not certified by peer review) is the author/funder, who has granted medRxiv a license to display the preprint in perpetuity. All rights reserved. No reuse allowed without permission.

correlation analysis between ANXA11, CYSRT1, DTD1, HLA-B, LTB4R, and TJP3 phosphoprotein abundances and MoCA for each group according to the gender. The redbordered areas show either positive or negative correlations. 
a

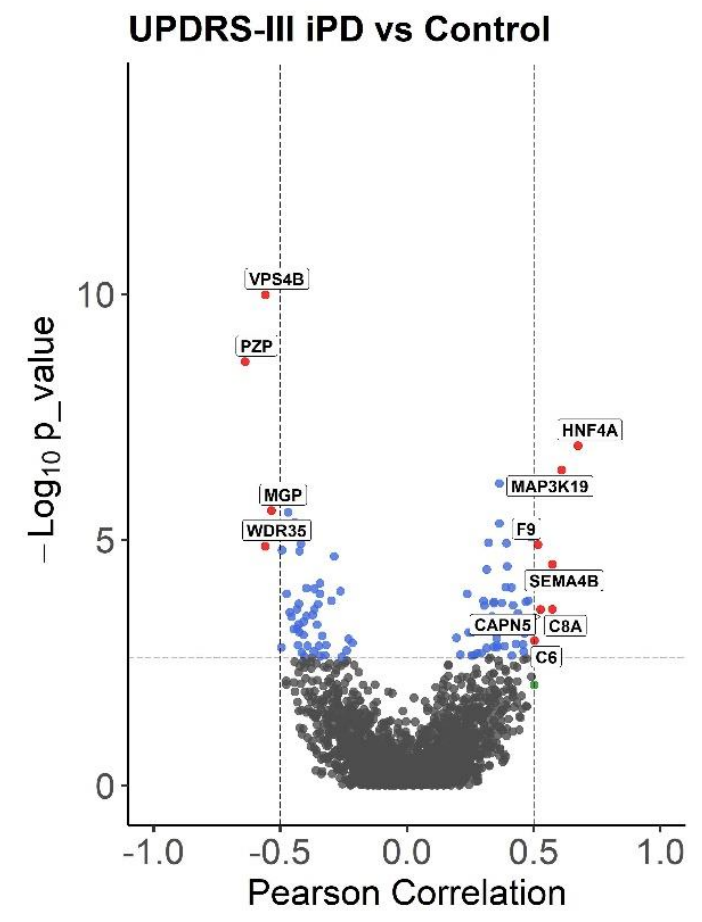

total $=2107$ variables

\section{UPDRS-III iPD vs Control}

b

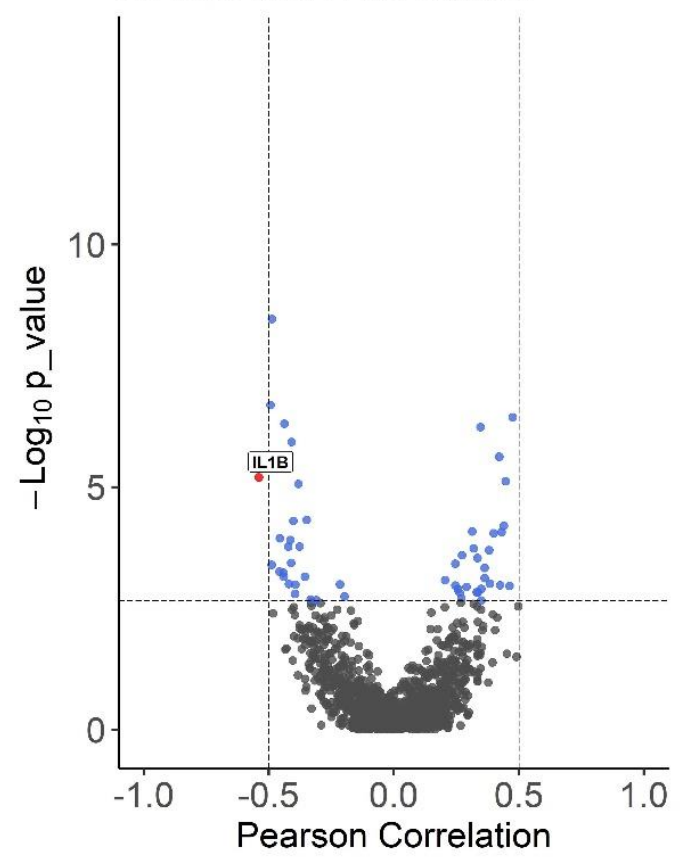

total $=1153$ variables
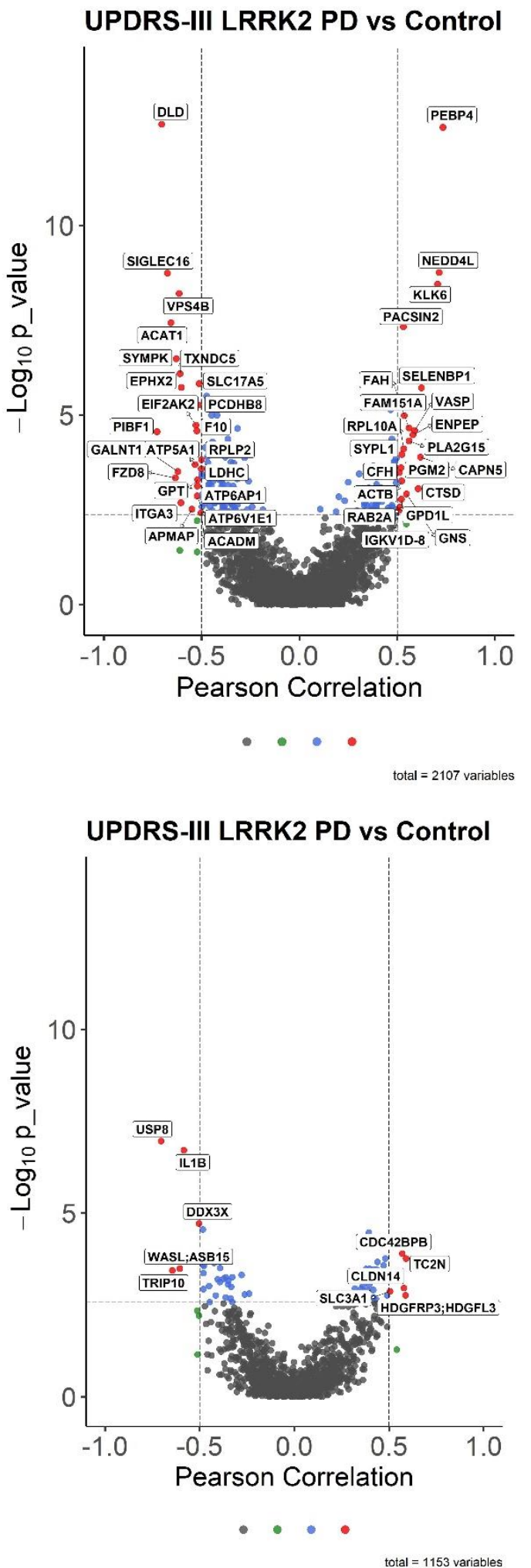
medRxiv preprint doi: https://doi.org/10.1101/2022.01.18.22269096; this version posted January 24, 2022. The copyright holder for this preprint (which was not certified by peer review) is the author/funder, who has granted medRxiv a license to display the preprint in perpetuity.

All rights reserved. No reuse allowed without permission.

Supplementary Figure 7. Correlations with clinical parameter, UPDRS-III. Pearson correlation scores and associated $P$-values $\left[-\log _{10}\right]$ of all a) protein and b) phosphoprotein intensities with the UPDRS-III score. Either all iPD patients (left) or LRRK2 PD patients (right) were included. Significantly correlated proteins with an FDR of $5 \%$ after Benjamin-Hochberg correction are labeled. 


\section{Supplementary Figure 8}

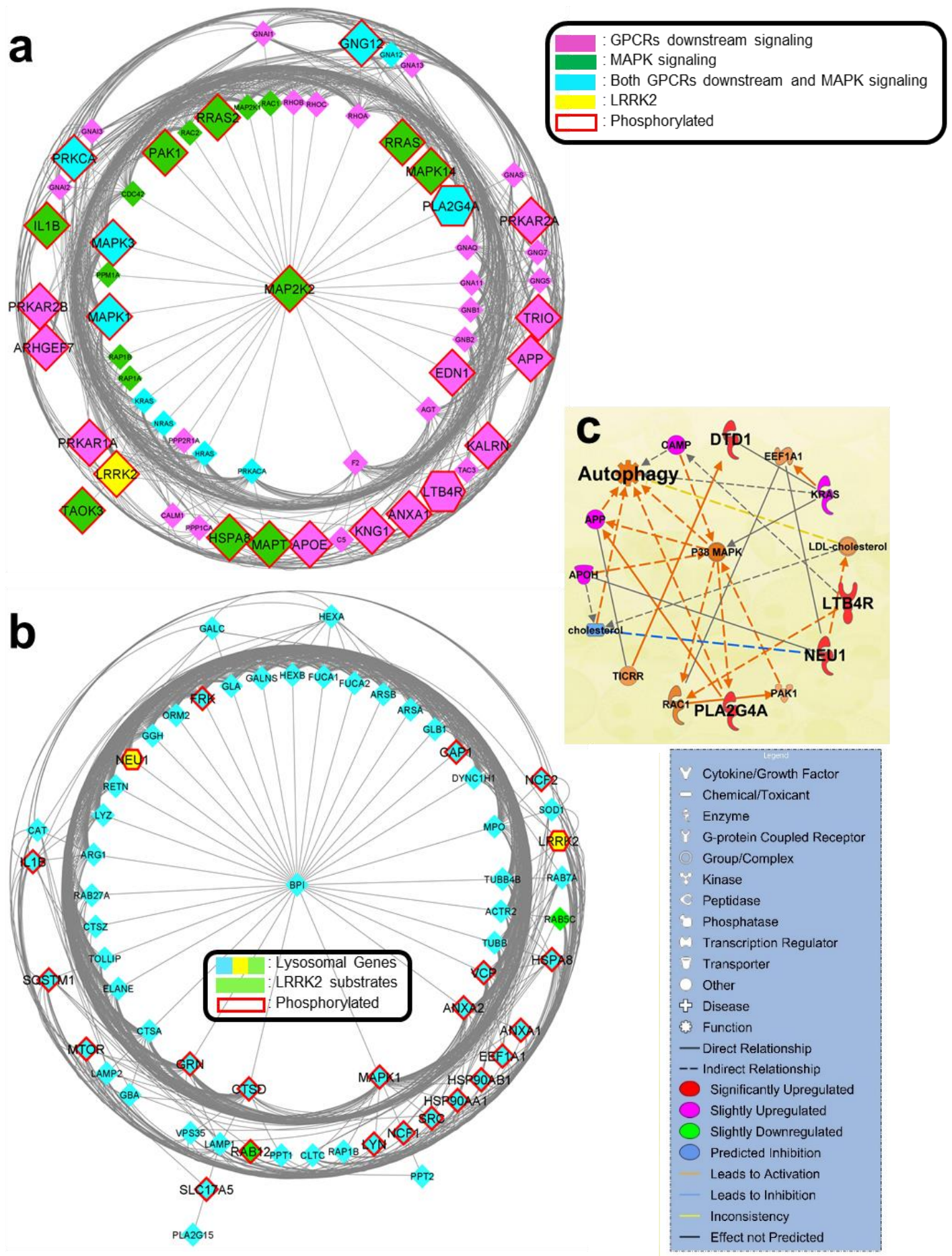

Supplementary Figure 8. Phosphoprotein disease biomarker network and pathway analyses. Enriched networks include a) GPCRs and MAPK signaling pathways and b) lysosome regulation and lysosomal disorder. c) IPA pathway analysis of the phosphoprotein disease markers related to the autophagy pathway. 


\section{Supplementary Figure 9}
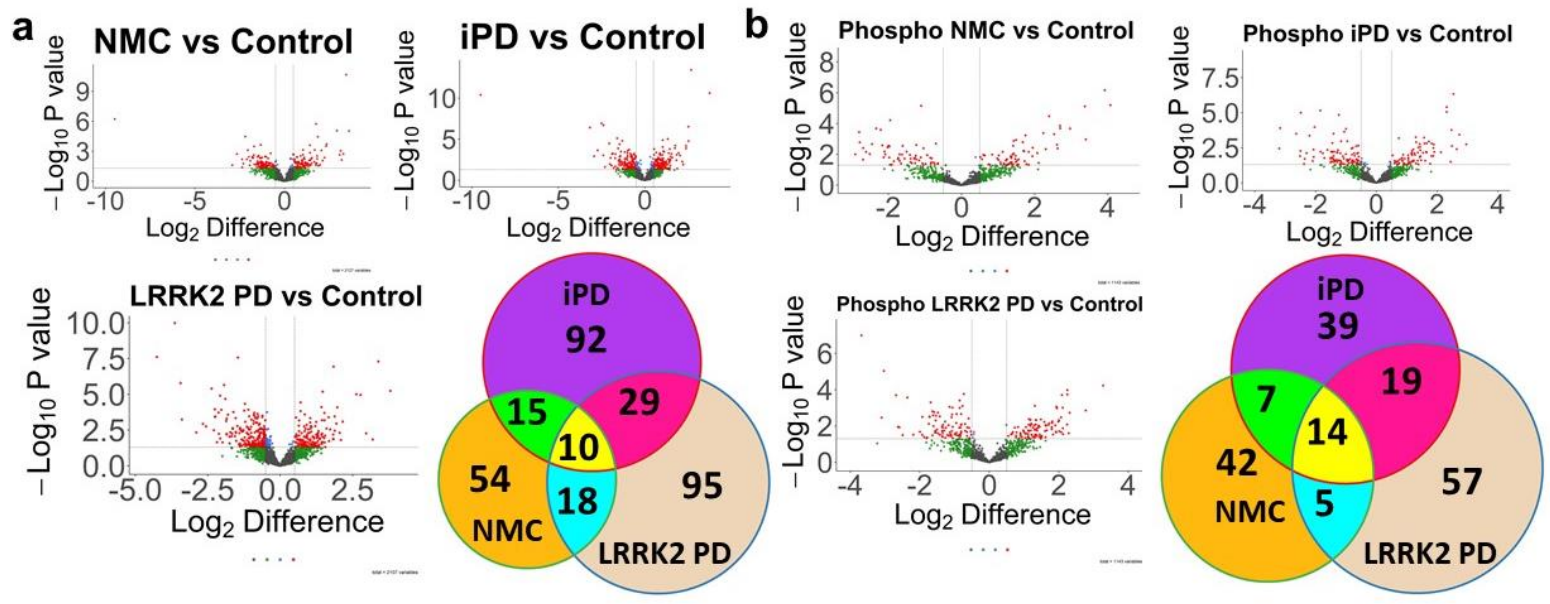

Supplementary Figure 9. Biosignature study design created on the training set. All three categories: NMC, iPD, and LRRK2 PD were compared to the Control group for (a) proteins and (b) phosphoproteins. Volcano plots were created for each comparison with cut-off values of $p$ value $=0.05$ and log base 2 difference $=0.5$, which equals to $\sim 1.414$ fold-change. Significantly up-regulated phosphoproteins from the three volcano plots were overlapped in Venn diagrams. 


\section{Supplementary Figure 10}
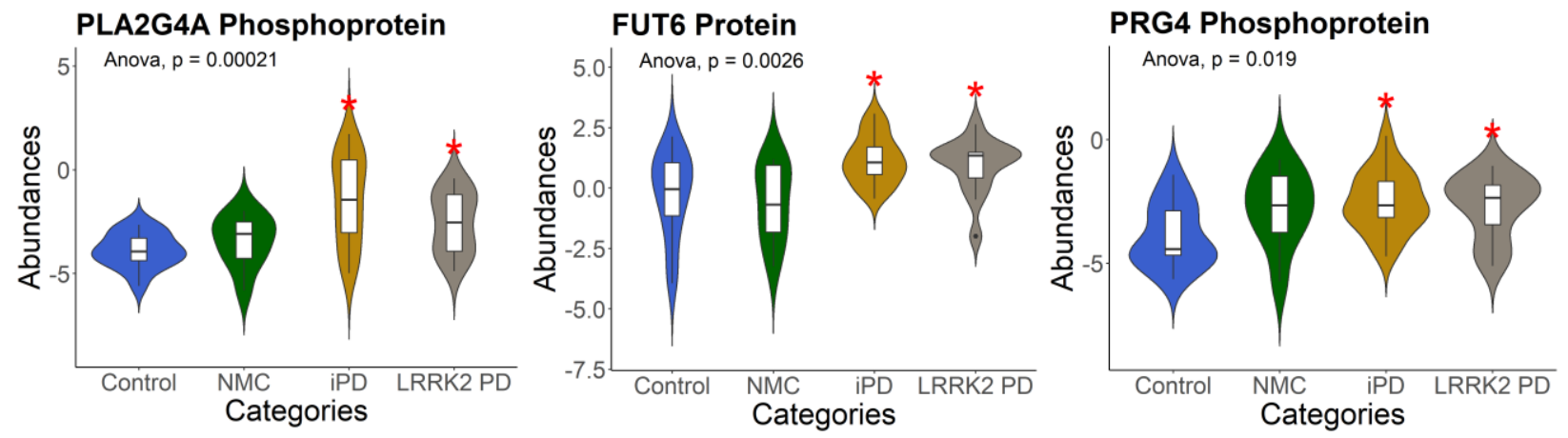

Supplementary Figure 10. The additional selected top disease biomarkers acquired from the training set. Violin plots of the statistically upregulated proteins and phosphoproteins from the training set in PD regardless of the LRRK2-G2019S mutation (disease markers). 


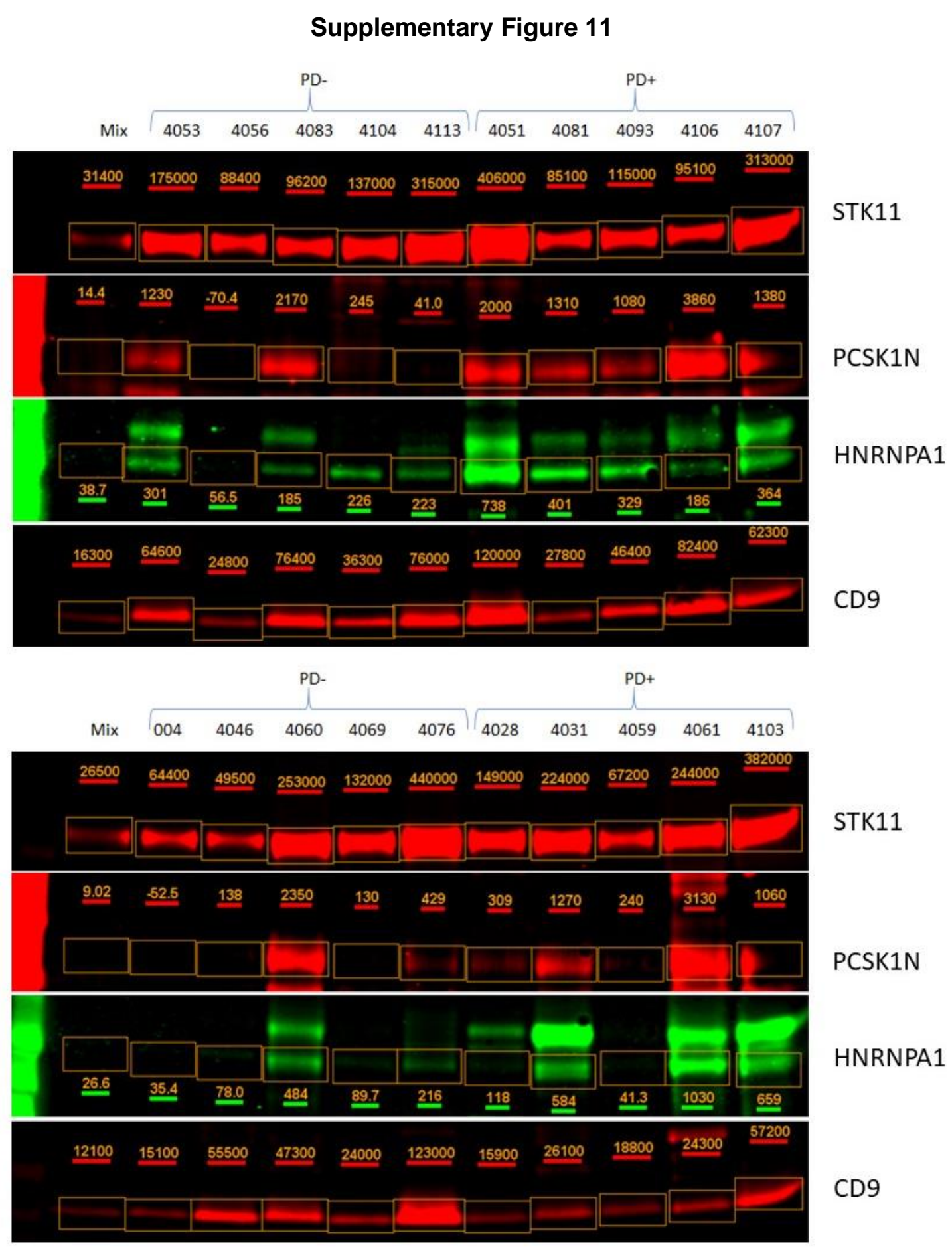

Supplementary Figure 11. Western blot analysis of CD9, STK11, PCSK1N, and HNRNPA1. All 20 urine EV samples were analyzed by Western Blot with anti-CD9, anti-STK11, antiPCSK1N, and anti-HNRNPA1 antibodies (2 blots for each type). An equal amount of pooled urine EVs was loaded in lane 1 of each gel. 
medRxiv preprint doi: https://doi.org/10.1101/2022.01.18.22269096; this version posted January 24, 2022. The copyright holder for this preprint (which was not certified by peer review) is the author/funder, who has granted medRxiv a license to display the preprint in perpetuity.

All rights reserved. No reuse allowed without permission.

\section{Supplementary Figure 12}
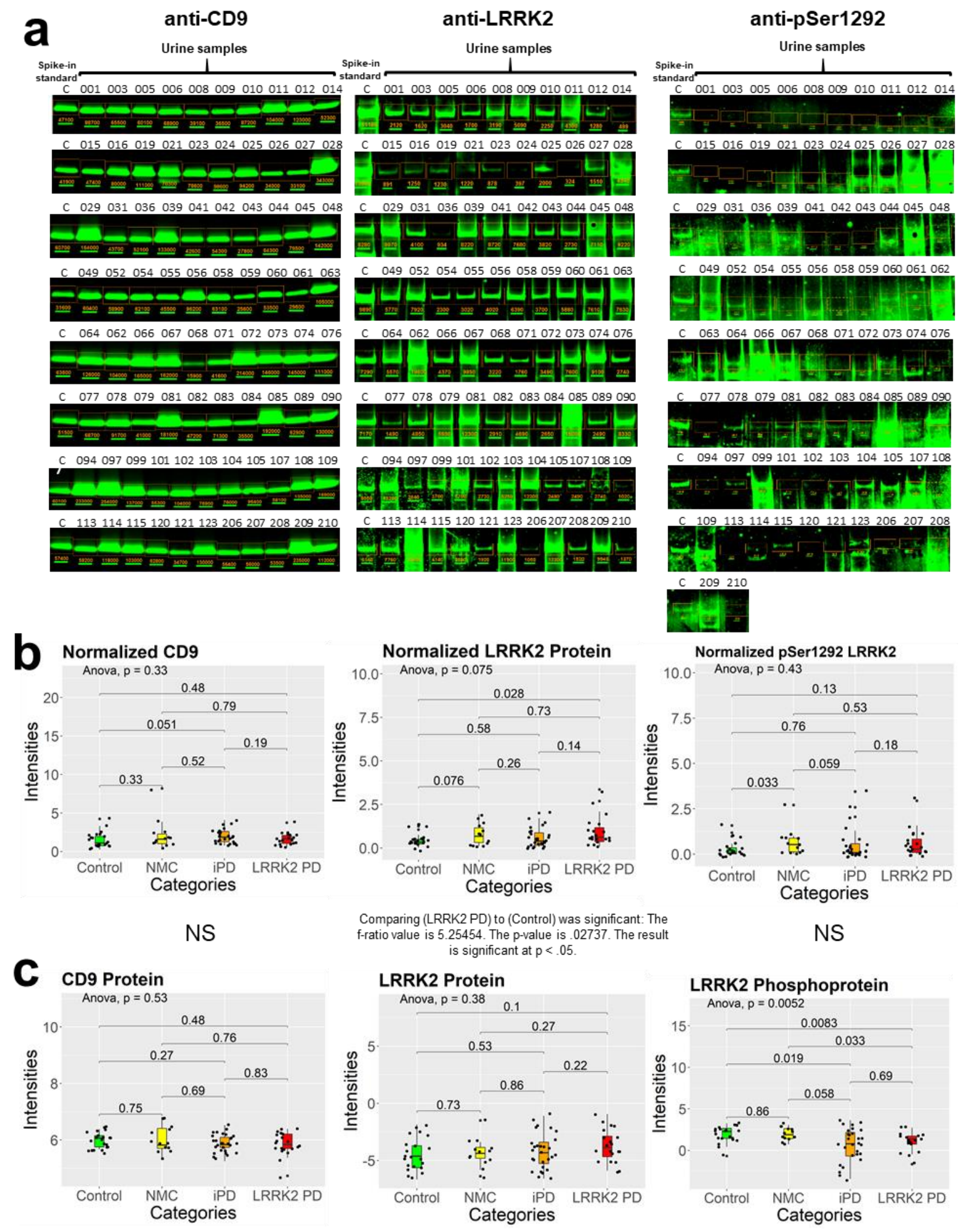

Comparing (LRRK2 PD) to (Control) was significant: The f-ratio value is 5.25454 . The p-value is .02737 . The result is significant at $p<.05$.
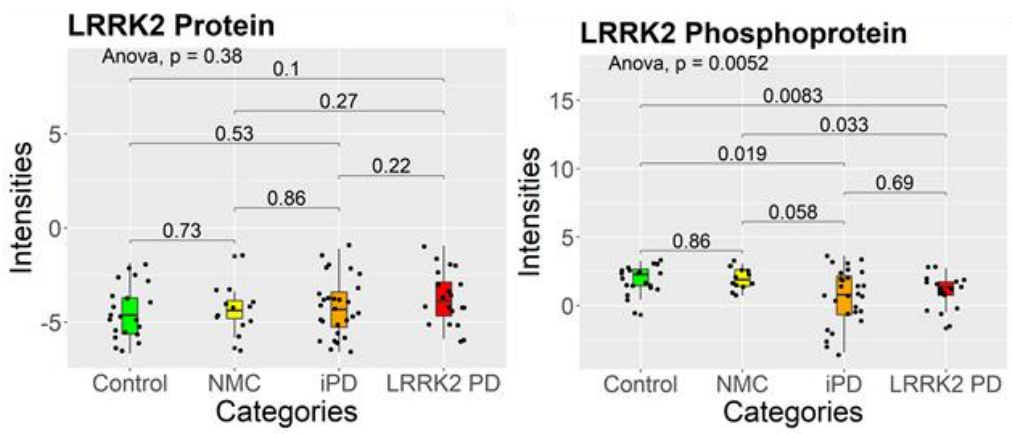
medRxiv preprint doi: https://doi.org/10.1101/2022.01.18.22269096; this version posted January 24, 2022. The copyright holder for this preprint (which was not certified by peer review) is the author/funder, who has granted medRxiv a license to display the preprint in perpetuity.

All rights reserved. No reuse allowed without permission.

Supplementary Figure 12. Western blot analysis of CD9, total LRRK2 and pSer1292-LRRK2. All 82 urine EV samples were analyzed by Western Blot with anti-CD9, anti-LRRK2, and antipSer1292-LRRK2 antibodies (8 blots for each type). An equal amount of a spike-in standard was loaded in lane 1 of each gel (pooled urine EVs for CD9 blots, recombinant LRRK2 for LRRK2 blots, and autophosphorylated recombinant LRRK2 for pSer1292-LRRK2 blots). a) Western blots from each analyzed target protein. b) Western blot-based quantitative comparison across all samples after normalization with an internal standard. c) Mass spectrometry-based quantitative comparison across all samples after normalization with an internal standard. 


\section{Supplementary Figure 13}
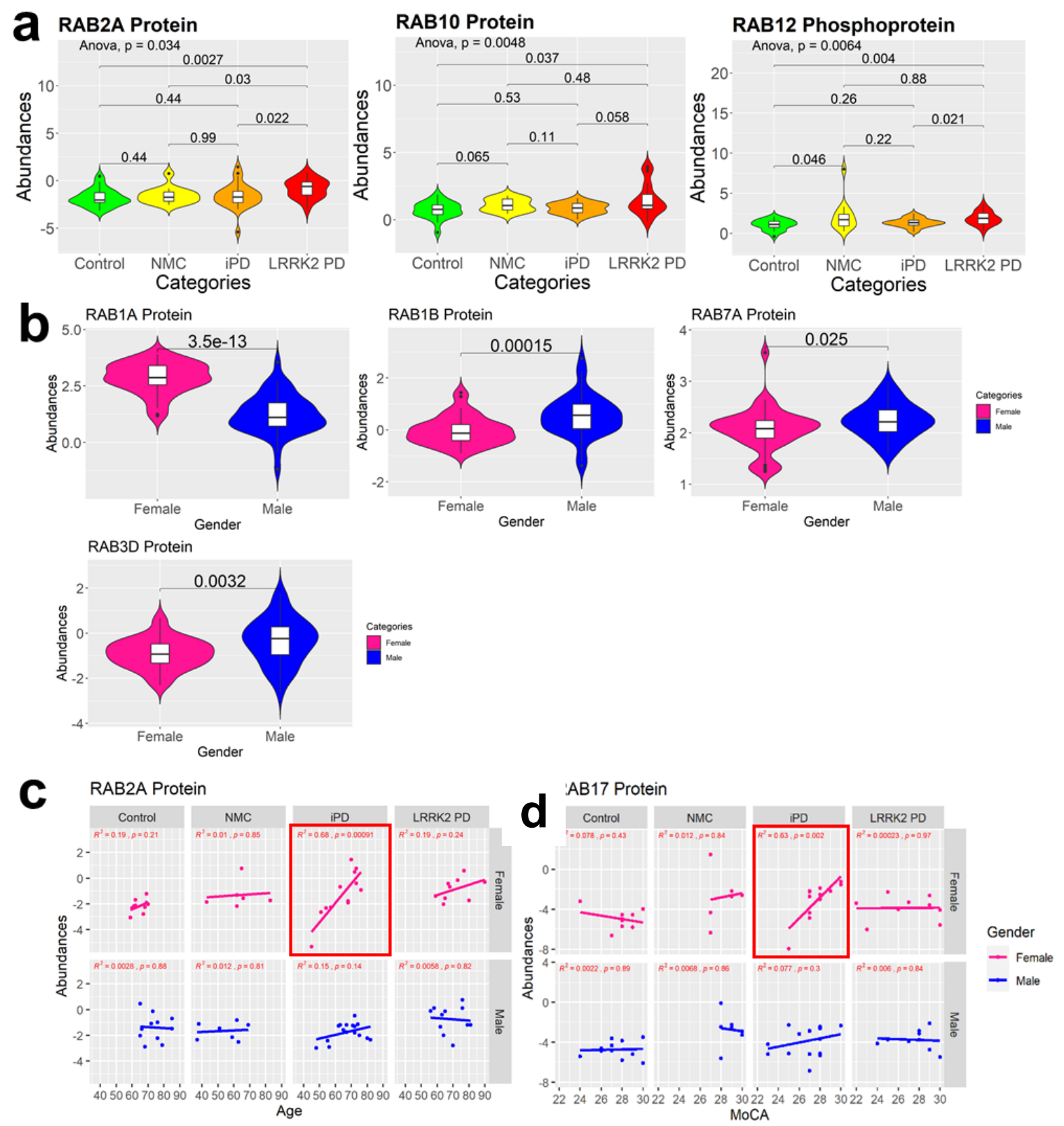

Supplementary Figure 13. Significantly changing Rab proteins and phosphoproteins. a) The EV levels of Rab2A and Rab10 were significantly higher than the control. b) Rab1A was expressed at lower levels in males; Rab1B, Rab3D, and Rab7A were expressed at higher levels in males. c) The correlation analysis between Rab2A protein abundances and age for each group according to gender. d) The correlation analysis between Rab17 protein abundances and MoCA for each group according to gender. The red-bordered areas show positive correlations. 


\section{Supplementary Table 1}

\begin{tabular}{|c|c|c|c|c|c|}
\hline \multicolumn{3}{|c|}{ Proteins } & \multicolumn{3}{|c|}{ Phosphoproteins } \\
\hline Accession & Gene Symbol & \# PSMs & Accession & Gene Symbol & \# PSMs \\
\hline P61026 & RAB10 & 1740 & P61026 & RAB10 & 57 \\
\hline Q15907 & RAB11B & 1400 & Q6IQ22 & RAB12 & 384 \\
\hline Q6IQ22 & RAB12 & 37 & P51153 & RAB13 & 13 \\
\hline P51153 & RAB13 & 171 & Q14966-1 & RAB7L1; RAB29 & 135 \\
\hline P61106 & RAB14 & 612 & Q86YS6 & RAB43 & 3 \\
\hline Q9H0T7 & RAB17 & 26 & P51149 & RAB7A & 2 \\
\hline Q9NP72 & RAB18 & 25 & P61006 & RAB8A & 290 \\
\hline P62820 & RAB1A & 622 & Q92930 & RAB8B & 34 \\
\hline Q9HOU4 & RAB1B & 828 & & & \\
\hline Q9NX57 & RAB20 & 2 & & & \\
\hline Q9UL25 & RAB21 & 166 & & LRRK2 Substrates & \\
\hline Q9UL26 & RAB22A & 55 & & Quantified & \\
\hline Q9ULC3 & RAB23 & 24 & & & \\
\hline P57735 & RAB25 & 107 & & & \\
\hline P51159-1 & RAB27A & 271 & & & \\
\hline 000194 & RAB27B & 159 & & & \\
\hline P61019-1 & RAB2A & 273 & & & \\
\hline Q13636 & RAB31 & 3 & & & \\
\hline Q13637 & RAB32 & 8 & & & \\
\hline Q9BZG1 & RAB34 & 5 & & & \\
\hline Q15286 & RAB35 & 437 & & & \\
\hline P20337 & RAB3B & 127 & & & \\
\hline 095716 & RAB3D & 331 & & & \\
\hline Q86YS6 & RAB43 & 38 & & & \\
\hline P20338 & RAB4A & 38 & & & \\
\hline P20339 & RAB5A & 433 & & & \\
\hline P61020 & RAB5B & 564 & & & \\
\hline P51148-2 & RAB5C & 1444 & & & \\
\hline P20340-2 & RAB6A & 58 & & & \\
\hline P51149 & RAB7A & 1861 & & & \\
\hline 014966-1 & RAB7L1; RAB29 & 268 & & & \\
\hline P61006 & RAB8A & 1016 & & & \\
\hline Q92930 & RAB8B & 576 & & & \\
\hline P51151 & RAB9A & 24 & & & \\
\hline
\end{tabular}

Supplementary Table 1. List of the 34 identified Rab GTPases, 12 of which are known to be LRRK2 substrates, and eight phosphorylated Rab GTPases. 